NBER WORKING PAPER SERIES

\title{
EMPOWERING WOMEN THROUGH EDUCATION: EVIDENCE FROM SIERRA LEONE
}

\author{
Naci H. Mocan \\ Colin Cannonier \\ Working Paper 18016 \\ http://www.nber.org/papers/w18016
NATIONAL BUREAU OF ECONOMIC RESEARCH
1050 Massachusetts Avenue
Cambridge, MA 02138 \\ April 2012
}

We thank Deokrye Baek and Luiza Pogorelova for research assistance and Leyla Mocan for helpful comments. The views expressed herein are those of the authors and do not necessarily reflect the views of the National Bureau of Economic Research.

NBER working papers are circulated for discussion and comment purposes. They have not been peerreviewed or been subject to the review by the NBER Board of Directors that accompanies official NBER publications.

(C) 2012 by Naci H. Mocan and Colin Cannonier. All rights reserved. Short sections of text, not to exceed two paragraphs, may be quoted without explicit permission provided that full credit, including $\odot$ notice, is given to the source. 
Empowering Women Through Education: Evidence from Sierra Leone

Naci H. Mocan and Colin Cannonier

NBER Working Paper No. 18016

April 2012

JEL No. I12,I15,I18,I21,I25,I28,J13,J18

\begin{abstract}
$\underline{\text { ABSTRACT }}$
We use data from Sierra Leone where a substantial education program provided increased access to education for primary-school age children but did not benefit children who were older. We exploit the variation in access to the program generated by date of birth and the variation in resources between various districts of the country. We find that the program has increased educational attainment and that an increase in education has changed women's preferences. An increase in schooling, triggered by the program, had an impact on women's attitudes towards matters that impact women's health and on attitudes regarding violence against women. An increase in education has also reduced the number of desired children by women and increased their propensity to use modern contraception and to be tested for AIDS. While education makes women more intolerant of practices that conflict with their well-being, increased education has no impact on men's attitudes towards women's well-being.
\end{abstract}

Naci H. Mocan

Department of Economics

Louisiana State University

2119 Patrick F. Taylor Hall

Baton Rouge, LA 70803-6306

and NBER

mocan@1su.edu

Colin Cannonier

College of Business Administration

Belmont University

1900 Belmont Boulevard

Nashville, TN 37212-3757

USA

colin.cannonier@belmont.edu 


\section{Empowering Women through Education: Evidence from Sierra Leone}

\section{Introduction}

Individuals with more education command higher earnings in the labor market, and the return to education is higher in developing countries (Psacharopoulos 1994, Schultz 2002). Education has a positive impact on other outcomes as well, such as the health status of individuals. More educated people are better producers of health; i.e. they are healthier in comparison to those with less education (Chou, Liu, Grossman and Joyce 2010; Grossman 1972a, 1972b; Lleras-Muney 2005). In addition, an increase in education of a particular generation has a positive impact on educational attainment of the next generation. Specifically, an increase in mothers' education raises the level of their offspring's education (Currie and Moretti 2003).

The impact of education on well-being is also documented at the country level. For example, education of the labor force, which is a measure of human capital in a country, is a significant determinant of economic growth (Hanushek and Kimko 2000). Although lowincome countries struggle with low levels of human capital as a barrier to development, many of these countries exhibit substantial discrepancies in education acquired by men vs. women. For example, school life expectancy is 0.5 years higher for men compared to women in countries where per capita income is less than $\$ 8,000 .^{1}$ The difference in expected schooling is about one year in favor of men among countries where per capita income is less than $\$ 4,000$, and it goes up to 1.4 years in countries where per capita income is less than $\$ 2,000$.

\footnotetext{
${ }^{1}$ School life expectancy is the total number of years of schooling a child is expected to receive. Information is based on education data obtained from UNESCO Institute for Statistics and income data from the World Bank.
} 
Gender difference in education is not an isolated phenomenon. Similar differences between men and women exist in developing countries in many other dimensions ranging from life expectancy to participation in politics, to the propensity for being exposed to violence. ${ }^{2}$ Eradicating these inequalities is important for a number of reasons, ranging from human rights to economic development. For example, drawing on Galor and Weil (1996), Lagerlöf (2003) shows that long-run economic development in Europe is related to the long-term trend in gender equality. Knowles et al. (2002) find that female schooling increases labor productivity across countries. Schultz (2002) indicates that countries which have reduced the inequality of educational attainment between men and women have grown faster. Furthermore, he argues that developing countries should reallocate public education resources in favor of women on the ground of efficiency, because social returns to education is higher for females than it is for males.

In this paper we use data from Sierra Leone to investigate whether education empowers women. Empowerment is usually understood as an exogenous change in the social or institutional structure to provide opportunities that were not previously available. Examples include changing the inheritance laws, providing property rights and voting rights, enacting laws and implementing quotas to increase participation in the labor market and in politics (see Duflo 2011 for a detailed discussion).

We define empowerment as having the knowledge along with the power and the strength to make the right decisions regarding one's own well-being. Because of social norms

\footnotetext{
${ }^{2}$ Gender inequalities are determined by complex historical, economic, social and cultural factors. For example, there is evidence for preference for sons in many developing countries such as China and India where the ratio of newborn boys to girls is greater than one. However, the preference for sons is not exclusively a developing country phenomenon. For example, Dahl and Moretti (2008) find evidence for preference for sons in the U.S.
} 
or a lack of economic power, women may feel obligated to submit to the wishes of others (e.g. their husband or father) even though doing so would clearly decrease their well-being in some circumstances. An example is the belief that the husband is justified in beating the wife if she refuses to have sex. We argue that women are empowered internally when they can take positions to protect their own well-being. In the example above, if a woman changes her belief and declares that violence against women in the form of wife beating is not justified, we call this an indication of empowerment. ${ }^{3}$ Another example is the attitudes towards the violent practice of female genital mutilation (FGM), which is physically and psychologically harmful to the woman affected. FGM is considered an extreme form of discrimination against women as well as a human rights violation (World Health Organization 2008). ${ }^{4}$ If a woman who lives in an FGM-practicing society alters her position on the appropriateness of the practice of FGM as a social norm, and supports its abolition, we consider this an indication of empowerment. ${ }^{5}$ The general idea of this paper is similar to the one pursued by Jensen and Oster (2009) where they investigated if access to cable TV modified women's attitudes toward domestic violence, preference for sons, and fertility.

We exploit variations in schooling that were generated by an exogenous education policy reform in Sierra Leone, implemented in 2001. The program increased access to primary education, and its intensity varied between different districts of the country. We employ the

\footnotetext{
${ }^{3}$ Our argument is consistent with that of some sociologists, who long hypothesized that objective inequalities between groups cannot be eliminated unless subjective beliefs about the legitimacy of these inequalities are eradicated (Weber 1964 [1922]; Durkheim 1933 [1893]).

${ }^{4}$ United Nations has launched a program in 2007 involving the UNICEF, the UNFPA and other public and private organizations to help stop the practice of FGM.

${ }^{5}$ It should be noted that male circumcision is a completely different practice than female genital mutilation. Male circumcision is not harmful and it has medical benefits (World Health Organization 2010)
} 
Sierra Leone Demographic and Health Survey, administered in 2008, to investigate the extent to which exposure to enhanced educational resources had an impact on acquired schooling. Using instrumental variables, we then estimate the impact of schooling on women's preferences regarding their own health and well-being. The identification strategy employed in the paper is similar to that used by Duflo (2001) and Osili and Long (2008), in which differences in program intensity between regions, and differences in the exposure to the program across age cohorts are exploited. Specifically, individuals who were of the primary school age (6 to 11 years) when the policy began in 2001 were exposed to the free and compulsory primary education, while older individuals could not benefit from the program.

We find that an exogenous increase in education triggers a change in attitudes that is empowering for women. One avenue through which education can modify individuals' behavior is through access to information. For example, when a woman becomes literate she can read and learn about the health risks of unprotected sex. Although we find evidence that a switch from being illiterate to literate has an impact on women's preferences in OLS regressions, we cannot say with confidence that this is a causal effect because the impact does not exist in instrumental variables regressions. This is because of the weak relationship between schooling and literacy in Sierra Leone. Alternatively, education can change preferences by influencing people's time discounting (Becker and Mulligan 1997), which can in turn impact behavior. Education can also improve the bargaining power of women in the household by increasing potential labor market earnings. The improved bargaining position may help women to take positions which do not conflict with their well-being. Although we cannot determine the particular channel through which education alters attitudes, we demonstrate that there is a strong net effect of education. 
It should be noted that even if increased internal empowerment could be a necessary condition to improve the well-being of women, it may not be sufficient to actually achieve a tangible change in outcomes, at least in the short-run, if external obstacles remain. We find indirect evidence on this when we analyze how education impacts men's attitudes towards women's well-being. We also analyze the extent to which education alters women's behaviors such as the use of modern contraceptives, whether she is tested for AIDS, as well as her desired number of children.

The remainder of the paper is organized as follows. Section 2 provides some background information on the educational system in Sierra Leone and the Free Primary Education policy. Section 3 describes the data used in the analysis. Section 4 describes the empirical strategy. Section 5 presents the results, and Section 6 is the conclusion.

\section{Free Primary Education (FPE) Policy in Sierra Leone}

Sierra Leone is one of the poorest countries in the world. In 2010, per capita gross national income was $\$ 340$. About 70 percent of females and half of males of the country are illiterate, and life expectancy at birth is 46 years. The population is about 5.5 million, and the fertility rate is 5 births per woman. The civil war, which broke out in 1991 and lasted for about a decade, killed at least 50,000 individuals (World Bank 2007). ${ }^{6}$ Even before the civil war, children faced challenges in having access to education. For example, parents were responsible for the payment of tuition and fees, teaching and learning materials and other expenses such as textbook purchases and exam fees. One consequence of the civil war was the destruction of

\footnotetext{
${ }^{6}$ Although the civil war officially ended in January 2002, the war has come to an end in 2001 for all practical purposes.
} 
infrastructure, including schools. By the end of the war, 1,270 primary schools had been destroyed, representing over 70 percent of all schools estimated to have been in existence before the conflict started (International Monetary Fund 2001). As a result, more than half of the primary schools had disappeared and this led to almost 70 percent of school-age children being out of school (International Monetary Fund 2001).

In 2001, Sierra Leone started implementing a policy of providing free primary education (FPE) for all pupils in government-owned and government-assisted schools. ${ }^{7}$ Financed largely from domestic public funds, donor contributions from international financial institutions and foreign governments, the FPE was part of an overall universal primary education policy aimed at constructing and rehabilitating basic education facilities as well as providing free access to education. The specific goal was to increase basic education (comprising six years of primary education and three years of secondary education) by making it free and compulsory.

By far, this has been the largest education funding initiative to be undertaken in Sierra Leone since its independence in 1961. During the period from 2001 to 2005, the government committed almost 20 percent of its expenditures (equivalent to 4 percent of the GDP) towards education. Almost half of all education expenditure was devoted to primary education (UNDP 2007). Consequently, the number of schools grew rapidly and by the end of 2005 there were at least 4,300 primary schools, approximately 30 percent of which was newly constructed since 2001.

Sierra Leone spans about 72,000 km squares (about 28,000 square miles, or roughly the size of South Carolina). The country is divided into 14 districts (see Figure 1). With the implementation of the FPE program, each district received new funding for education and the

\footnotetext{
${ }^{7}$ At least 95 percent of all recognized primary and secondary schools are either government-owned or government-assisted (World Bank 2007).
} 
program was associated with a pronounced change in primary school enrollments. The number of students doubled from 0.6 million to 1.3 million children between 2001 and 2004, and the primary school gross enrollment rate exceeded 100 percent in 2004. ${ }^{8}$ In 2004, Sierra Leone had the highest primary school enrollment rates amongst all Sub-Saharan countries (World Bank 2007).

\section{Data}

We use data from the 2008 Sierra Leone Demographic and Health Survey (SLDHS). The SLDHS is part of a broader program of demographic and health surveys conducted in other developing countries. The SLDHS is a cross-sectional nationally representative household survey and is the first of this kind in Sierra Leone. ${ }^{9}$ Interviews for the SLDHS were conducted from April to June 2008. ${ }^{10}$ The data contain information for over 10,000 individuals who were aged 15-49 (females) and 15-59 (males) in 2008. Using the age reported in 2008 and the reported birth dates, we identified individuals who were 8 to 11 years old in 2001 . This particular group was exposed to the FPE policy. We similarly identified those who were 15-21 years old in 2001. These individuals were beyond the primary school age during the

\footnotetext{
${ }^{8}$ Primary school gross enrollment rate for any given year is the number of students enrolled in primary school expressed as a percentage of the population of primary-school-age children. In Sierra Leone, the official primary school age ranges from 6 to 11 years. It is possible for the primary school gross enrollment rate to be above 100 percent. This is because some of the enrolled may consist of older-aged children who have returned to school after the war, pre-primary school-aged kids attending primary school as well as repeaters.

${ }^{9}$ Demographic and Health Surveys (DHS) have been conducted for more than 75 developing countries since 1985 as repeated cross sections. In most of these countries, there are several waves of the survey. In Sierra Leone, the 2008 DHS is the only one that is done so far.

${ }^{10}$ While funding for the survey came from a variety of international agencies, the collection, processing and dissemination of the data were undertaken by Statistics Sierra Leone in collaboration with the Ministry of Health and Sanitation, with technical support provided by ORC Macro International.
} 
implementation of FPE and could not benefit from the policy. We provide more details on the identification strategy in the next section.

Because the district level information on the amount of funding is not available, we impute funding received by each of the 14 districts by multiplying the total government spending on the FPE program in 2004 (which was about 14 billion Le, or about $\$ 6$ million at the prevailing exchange rate) with the share of each district in local government development grants. Information on the district-level share of local government development grants and matching grants was for fiscal year 2006 (see UNDP 2007, p.79), while total funding allotment for primary education came from the Government of Sierra Leone Budget and Statement of Economic and Financial Policies for the financial year 2004. The resource variable per district is the logarithm of funding received by the district per 100 teachers.

We employ four variables as measures of women's empowerment. As discussed in the introduction, we adopt the definition of empowerment as one's ability to make correct decisions about the issues that impact one's own well-being. We consider affirmative answers to the following questions as being consistent with a woman's well-being: (i) whether a wife is justified in refusing to have sex when she is tired or not in the mood; (ii) whether a wife is justified in refusing to have sex with her husband if she knows he has a sexually transmitted disease (STD); (iii) whether female genital mutilation should be stopped as a custom. The fourth question asks the respondent "whether a husband is justified in hitting or beating his wife if she refuses to have sex with him." If the answer of the woman to this question is in the affirmative, we consider her beliefs being inconsistent with her well-being.

We also gauge the preference towards fertility, measured by the number of desired children. An alternative measure would have been the number of children ever born, but 
because we focus on young individuals (who are 15 to 28 years old in 2008) their fertility is unlikely to be completed. Furthermore, desired fertility is conceptually different from completed fertility, where the latter may diverge from the former for a variety of reasons. Two additional variables gauge whether the woman uses modern contraceptive methods and whether she has ever been tested for AIDS.

Column (2) of Table 1 displays the means and standard deviations of the full sample of females who were either 8-11 or 15-21 in 2001. The information provided in the table pertains to 2008 when the individuals were aged 15 to 28 . Of this group, those who were 8 to 11 years old in 2001 were exposed to the FPE. This is the "treatment" group, the descriptive statistics of which are provided in column (3). Those who were 15 to 21 years old in 2001 constitute the “control" group, listed in column (4).

On average, women desire to have 4.7 children over their lifetime. The number of desired children for women in the treated group is 4.2 , while it is 4.9 for those who are not exposed to the FPE program. The rate of modern contraceptive use is lower for those in the treatment group, but this is likely because the average age in this group is lower (16.5) in comparison to the average age in the control group (25.5). This is also the likely reason for the difference in the rate of having been tested for AIDS between the two groups.

The proportion of women who indicate that a wife is justified in refusing sex when she is tired, is higher among the control group. The same is true for the question that asks whether a wife is justified in refusing to have sex with her husband if he has a sexually transmitted disease. It is somewhat puzzling that the proportion of affirmative answers is higher for the control group which has less education. On the other hand, the proportion of married women is larger in the control group. To the extent that married women have better information and 
experience on the issues raised by these two questions, it could be reasonable to have higher proportion of affirmative answers among the control group. The proportion of women who thinks that wife beating can be justified is lower in the treatment group, and the proportion of women who thinks that female genital mutilation should be discontinued is higher among the treatment group.

Although the individuals who are exposed to the FPE are younger than those who are not exposed, the former group has more schooling on average than the latter as expected (4.4 years vs. 2.1 years). The data set contains information on religious affiliation and ethnic background. Islam and Christianity are the two dominant religions in Sierra Leone; and Temne and Mende are the two largest ethnic groups. We also have information on whether the person resides in an urban or rural area. The wealth of the person is measured by dummy variables titled Wealth1, Wealth2 and so on, to indicate the wealth quintile to which the individual's household belongs. Total wealth is calculated using all household assets, including cars and television sets, as well as dwelling characteristics such as flooring material, type of drinking water source, toilet facilities. ${ }^{11} \mathrm{TV}$, Radio and Fridge indicate whether the household of the individual has these consumer durables. These variables are correlated with wealth. In addition, TV and radio may have a direct impact on attitudes because they may enable the person to have access to information. For example, Jensen and Oster (2009) show that the introduction of cable television into rural India has changed the reported acceptability of domestic violence toward women and the preference for sons. Chong and la Ferrara (2009) report that access to a particular TV channel, which has monopoly over soap operas (which

\footnotetext{
${ }^{11}$ For the details of the creation of this measure, see the DHS website at http://www.measuredhs.com/data/Data-Quality-and-Use.cfm\#CP_JUMP_5373 (accessed February 15, 2012).
} 
typically contain themes related to criticism of traditional values and female empowerment and emancipation) is associated with increased divorce rates.

The data set does not contain information on the region of birth, childhood place of residence or the place of education. As a result, we cannot determine whether the individual has received her education in a given region and then moved and was surveyed in 2008 while living in a different region of the country. The basic assumption behind empirical analyses is that individuals have received their education in the same region where they were interviewed in 2008. However, later in the paper we identify those who have lived in the same residence continuously since the school years. Using this sub-sample of individuals, who clearly have not relocated since the elementary school age, we obtain similar results.

\section{Empirical Strategy}

We first estimate the impact of the education policy on schooling acquired by women using a specification depicted by Equation (1) below.

$$
\mathrm{S}_{i j t}=\beta_{0}+\beta_{1} \text { FPECohort }_{i}+\mathbf{X}_{i} \boldsymbol{\Omega}+\gamma_{\mathrm{j}}+\delta_{\mathrm{t}}+\boldsymbol{\varepsilon}_{i j t}
$$

where $\mathrm{S}_{i j t}$ stands for years of education (measured in 2008) of individual $i$, in region $j$, who was born in year $t$. FPECohort $i$ is a dichotomous indicator which takes the value of one if the cohort of the individual was exposed to the Free Primary Education (FPE) policy, and zero otherwise. The primary school age in Sierra Leone is 6-11. Those who were six years old in 2001 when the FPE policy started were 13 years old in 2008 when they answered the survey questions. However, the minimum age of those who were part of the survey in 2008 is 15 and these individuals were 8 years old in 2001. Therefore, we consider those individuals who were 
8 to 11 years old in 2001 (who were 15 to 18 in 2008) as part of the treatment group; and FPECohort takes the value of one for these individuals. At the start of the policy in 2001, those who were above the primary schooling age (e.g. those who were 12 or 13) were nevertheless allowed to enroll in school. Because these older children have returned to school, the primary school gross enrollment rate rose above 100 percent (World Bank 2007). Even in 2004, more than half of the children enrolled in the first grade of the primary school were older than six years. This was true of the other grade levels of the primary school as well (World Bank 2007). This means that children who were older than 11 years of age in 2001 could have also benefitted from the program. Therefore, we chose as the control group those who were 15 to 21 when the implementation of the FPE started. This older group was not exposed to the policy. The vector $\boldsymbol{X}_{\boldsymbol{i}}$ includes attributes of the individuals such as religion, ethnic background, residence in an urban area, and indicators of wealth. The equation includes district fixedeffects $\gamma_{\mathrm{j}}$, year of birth fixed effects $\delta_{\mathrm{t}}$, and a standard white noise error term $\varepsilon_{i j t .}{ }^{12}$

An alternative specification is depicted by Equation (2) where schooling is assumed to be impacted not only by exposure to the treatment by the FPE, but also by the intensity of the program.

$$
\mathrm{S}_{i j t}=\varphi_{0}+\varphi_{1}\left(\text { FPECohort }_{i} * \mathrm{R}_{j}\right)+\mathbf{X}_{i} \boldsymbol{\Psi}+\xi_{\mathrm{j}}+\theta_{\mathrm{t}}+\mathbf{v}_{i j t}
$$

where $R_{j}$ represents per teacher spending allocated to district $j$. As described in the introduction, because of the devastation of the infrastructure during the civil war, there was

\footnotetext{
${ }^{12}$ Sierra Leone is divided into four main regions (East, West, North and South) comprising a total of 14 districts where one leader from each district has a seat in the country's parliament. The design of the SLDHS was done to take this district-level grouping into consideration. Figure 1 shows the division of these districts according to regions.
} 
significant damage to school buildings. While the government could not increase the number of teachers at the end of the civil war in 2001, it started repairing damaged classrooms and building new schools. The intensity of this effort, which differs between regions, measured as $\log$ spending per 100 teachers in 2004, is represented by $R_{j} . \quad \boldsymbol{X}_{i}$ is a vector of personal characteristics of the individual as before; $\xi_{\mathrm{j}}$ and $\theta_{\mathrm{t}}$ represent region and year-of-birth fixedeffects, respectively.

To investigate the extent to which schooling had an impact on women's preferences, we estimate versions of Equation (3).

$$
\mathrm{Y}_{i j t}=\alpha_{0}+\alpha_{1} \mathrm{~S}_{i j t}+\mathbf{X}_{i} \boldsymbol{\Phi}+\mu_{\mathrm{j}}+\lambda_{\mathrm{t}}+\tau_{i j t}
$$

where $\mathrm{Y}_{i j t}$ represents the response of individual $i$ who was born in year $t$, and who resides in district $j$ to questions on health, sexual activity and husband-wife relations, shown in Table 1. $S_{i j t}$ stands for the level of schooling of the individual; $\mu_{\mathrm{j}}$ and $\lambda_{\mathrm{t}}$ represent region fixedeffects and year-of-birth fixed-effects, respectively. Because unobservable characteristics of the person, captured by the error term $\tau_{i j t}$, impact her preferences (Y) and because these unobservables could be correlated with her level of schooling (S), Equation (3) is estimated using instrumental variables, where schooling is instrumented by exposure to the FPE and intensity of the program in the district $\left(\right.$ FPECohort $\left.{ }_{i} * R_{j}\right)$.

\section{Results}

Column (1) of Table 2 displays the result obtained from estimation of equation (1), where schooling is regressed, among other controls, on FPECohort, which is the dummy variable that measures the individual's exposure to the FPE program. The result indicates that 
being a member of the birth cohort that was exposed to the program increases women's schooling by 0.5 years in comparison to the older cohorts that were not exposed to the program. The specification displayed in column 2, based on equation (2) provides the same inference. The advantage of this specification is that it allows for variation in resource allocation between the districts and that year-of-birth fixed-effects are included. Column (3) reports the same specification as in column (2) with the exclusion of all covariates other than (FPECohort $* R$ ). The estimated impact of the program remains the same.

The specification displayed in Column (2) of Table 2 is the basic first-stage regression of the impact of the FPE program on schooling. In Table 3A we provide the results of the instrumental variables regressions where women's behavior regarding using modern contraceptives and testing for AIDS is analyzed, along with the analysis of their preferences regarding physical violence against them, and the issues that impact their health.

In each specification the primary variable of interest is the years of schooling, which is instrumented by the interaction of the cohort exposure dummy and the education funding received by the district of residence. The regressions employ sampling weights and standard errors are clustered by year of birth and district. Columns (1) and (2) of Table 3A show that an additional year of education increases women's propensity to use modern contraception by about 12 percentage points and the propensity for being tested for AIDS by 11 percentage points. These are substantial impacts as the proportion of women who use modern contraception in the sample is 17 percent, and 13 percent of the women in the sample has been tested for AIDS. Column (3) of Table 3A demonstrates that an additional year of schooling generates a decrease in the desired number of children by 0.34 . The fertility rate in Sierra Leone is 5 children per woman and the desired number of children in our sample is 4.7 . Thus, 
according to our estimate, the desired number of children of a woman who completes primary schooling and receives six years of education will be 2 fewer children than the sample average (or a total of 2.7 children). Whether this decrease in desired fertility would translate into an actual decline in the number of children born depends on the interplay between the woman's and her husband's preferences along with other social expectations and pressures. As we demonstrate below, an increase in schooling for men does not translate into a significant change in their preference for the desired number of children.

Columns (4) to (7) of Table 3A present the results where we investigate the impact of education on women's attitudes regarding their own health and well-being. Columns (4) and (5) display the results of the models where the dependent variable measures whether the woman believes it is justified to refuse to have sex with the husband if the wife is tired (column 4), or if the husband has a sexually transmitted disease (column 5). In both cases, an increase in schooling makes women more likely to answer in the affirmative, although the impact is not statistically significant in case of the "refusing sex when tired" question. An increase in education by one year increases a woman's propensity by 11 percentage points to declare that a wife is justified to refuse sex when the husband has an STD. At the sample mean this translates into an increase in the attitude by 23 percent.

Columns (6) and (7) of Table 3A present the results where the attitudes towards physical violence against women are analyzed. Column (6) shows that one additional year of schooling reduces women's propensity to approve wife beating by about 10 percentage points. About 36 percent of all women in the sample believe that wife beating is justified (see Table 1). Thus, the result reported in column (6) represents a sizable impact on the attitudes regarding acceptability of violence against women. Similarly, Table 1 shows that about only 30 percent 
of women in the sample believe that female genital mutilation should be discontinued. An increase in education by one year, triggered by the FPE program, increases women's propensity to declare that female genital mutilation should be stopped by about 9 percentage points (column 7 of Table 3A). Running the models with no control variables provided very similar results, as shown in Table $3 \mathrm{~B}$.

In summary, the results demonstrate that an increase in schooling alters women's preferences in favor of protecting their own well-being. An increase in education makes women more likely to declare that a woman is justified in refusing sex when there is a health risk or when she is tired. An increase in education also makes women more likely to disapprove acts of physical violence against them. These results indicate that education empowers women.

\section{Does Literacy Matter?}

In the SLDHS, literacy was evaluated based on the ability of the respondents to read a sentence placed in front of them. We created a dummy variable, titled Literate, that takes the value of one if the individual was able to read the whole sentence. We defined a second variable, Literate2, which identifies those who could read the entire sentence as well those who could read only parts of the sentence. This second variable identifies those who are literate or are semi-literate. As shown in Table 1, 26 percent of the women in our sample is literate, and 32 percent is literate or semi-literate. This is consistent with the 30 percent literacy rate for females who are 15 years of age and older in 2009, reported by the World Bank (UNESCO Institute for Statistics 2011). ${ }^{13}$

\footnotetext{
${ }^{13}$ The literacy rate for men 15 and over was 53 percent in 2009.
} 
Table 4 presents the OLS results where all outcome variables are regressed on Literate. The results are similar to those reported in Table 3A. Being literate is associated with a higher probability of using modern contraception, a higher probability of having been tested for AIDS and a smaller number of desired children. Literate women are more likely to agree with the statement that a wife is justified in refusing sex if she is tired, or if the husband/partner has an STD. Women who are literate are also less likely to indicate that wife beating is justified and more likely to declare that female genital mutilation should be stopped. The same results are obtained when we employed Literate $2 .^{14}$

These OLS results may not represent the causal effect of literacy if unobserved factors that are correlated with the likelihood of being illiterate are also related to women's preferences. Therefore, we ran the instrumental variables regressions reported in Table 3A, replacing the schooling variable with Literate or Literate 2 to investigate whether a switch from being illiterate to literate (or a switch from being illiterate to being semi-literate or literate) causes a change in women's preferences. The results, which are not reported, show that the coefficient of literacy is not significant in any of the seven regressions, regardless of whether we use Literate or Literate2. Furthermore, this result seems to emerge because of the lack of power in the first-stage regressions, where the F-values of the instrument are very low in each regression.

Because this result is somewhat surprising, we investigated the relationship between reported schooling and literacy by exposure to the FPE program. Table 5 reports the average literacy rate by education among those who are part of the control group (those who are not exposed to the FPE program) as well as for those who are treated by the program. Among

${ }^{14}$ These results are not reported in the interest of space. 
those with zero years of schooling, the literacy rate is essentially zero in both groups. Among the group of women who have 1 to 3 years of schooling, the literacy rate is zero if they are part of the control group (aged 21-28 in 2008), and about eight percent of this group is semi-literate or literate. Of the women who have 1-3 years of education and who are part of the treatment cohort (aged 15-18 in 2008), the literacy rate is 7.7 percent; and 38.5 percent of this group is semi-literate or literate. The same pattern emerges among those with 4-6 years of schooling; that is, the literacy rate is higher in the treatment group, but it is far less than 100 percent. The fact that the literacy rate is extremely low among the control-group women who have some primary education ( 1 to 6 years) may be attributable to the fact that some of these women went to school during the civil war years and therefore it is likely that they did not receive high quality instruction during those years. On the other hand, the FPE program started post-civil war. Therefore women, who are part of the treatment cohort and who went to school under the FPE program, are not impacted by the interruptions of the civil war. It is remarkable that less than one-third (29.6 percent) of those who received 4-6 years of schooling under the FPE program can read a complete sentence. ${ }^{15}$

The literacy rates are 100 percent for those who have at least seven years of education. This is true both in the control group and in the treatment group. This result is not because of the effectiveness of the secondary school system. Rather, it is because of the fact that to enroll in the secondary school, the student must take an exam, and those who are still illiterate after having completed the $6^{\text {th }}$ grade cannot plausibly pass the exam to qualify for the $7^{\text {th }}$ grade.

Taken together, these results indicate that an increase in schooling changes the attitudes of women regarding the issues that matter for their well-being but that this effect is not due to

\footnotetext{
${ }^{15}$ Such poor education outcomes are common in developing countries. For example, Banerjee et al. (2007) indicate that in India 44 percent of the children aged 7-12 cannot read a basic paragraph.
} 
women's improved reading ability due to increased schooling. The mechanism through which education impacts attitudes is unclear. Education's impact could be due to the exposure to teachers/lectures even though such exposure does not significantly enhance literacy. It could also be due to some other channel such as socialization experiences while in school; it could also be the result of multiple influences.

\section{The Impact on Men}

In this section we investigate the extent to which the increase in educational attainment due to the FPE program has impacted men's attitudes regarding women's well-being. Table 6 displays the descriptive statistics for men. A comparison between men and women reveals an interesting and surprising picture. For example, while 56 percent of women indicated that a wife would be justified in refusing sex when she is tired (see Table 1), 68 percent of men believe that such a refusal is justified. Similarly, the proportion who thinks that a wife is justified in refusing sex if the husband has an STD is higher among men than women. Along the same lines, the proportion of men who think that wife beating is justified is lower than the proportion of women who think the same $(0.23$ vs. 0.36$)$, and the proportion of individuals who think that female genital mutilation should be discontinued is higher among men than women (0.38 vs. 0.30$)$ These are surprising findings because one would expect that the rate of support for the statements in favor of women's well-being would be higher among women. This outcome, however, is not an artifact of the data we employ. It is consistent with a health report on Sierra Leone (Statistics Sierra Leone and ICF Macro 2009) and could be a reflection of a culture that fosters particular behavioral patterns for women and promotes a subservient attitude to men. 
Table 7 presents the instrumental variables regressions for men. This table is the counterpart of Table 3A, which presented the same information for women. Table 7 shows that, as was the case for women, an additional year of schooling increases the propensity to use modern contraception and the likelihood to have been tested for AIDS among men. On the other hand, an increase in education on the margin (the mean years of schooling is 5 years among men) has no impact on men's attitudes towards women's well-being.

\section{Potential Migration}

The data set does not allow us to identify the district in which the individuals received their education. There is, however, one question in the survey that asks individuals how long (in years) they have been living in their current residence. For each individual we calculate the number of years since they completed their schooling. If the number of years in the current residence is greater or equal to the years since the highest grade completed, the individual has not moved to another district since completing schooling. We call such people "non-movers." Note that the question about residence pertains to the location of the physical dwelling and not to the city or the district of residence. This means for example, that a person who has completed her schooling 10 years ago but lived in the same residence continuously for only 9 years is considered a "mover." In reality this particular individual may have moved to another

residence in the same district -- thus her place of current residence and her place of schooling may be the same. However, there is no way to distinguish between the cases in which the move was to a new physical home and in which the move was to a new region. Put differently, this crude measure forces us to classify anybody as a "mover" who has not lived in the current place of residence longer than the number of years since schooling is completed. As a result, we end up with those who definitely went to school in the same district as where they were 
surveyed in 2008 , but we omit those who have moved to a different residence in the same district. Consequently, we lose more than 1,000 observations, some of which are non-movers who had to be classified as movers.

The results obtained from this sample of "non-movers" are presented in Table 8 for women. The point estimates of schooling are smaller in some cases in comparison to those reported in Table 3A, but the main inference does not change. Although the impact of schooling on attitudes of women is not statistically significant at conventional levels for questions regarding sexual relations in case of a sexually transmitted disease, education has a statistically significant impact on questions pertaining to violence against women. Specifically, an increase in education has a negative impact on the propensity to declare that wife beating is justified and it increases the propensity to declare that female genital mutilation should be eradicated.

\section{Conclusion}

The impact of schooling on earnings is well-documented and an increase in education improves health outcomes. These direct impacts of education on human capital and labor productivity are important ingredients for economic development. Increased education can produce other benefits for the individuals and the society by changing attitudes and preferences. $^{16}$ In this paper we investigate whether an increase in schooling changes women's preferences regarding the issues that are directly related to women's well-being.

\footnotetext{
${ }^{16}$ For example, Dee (2004) finds that increased educational attainment improves civic engagement in terms of voting behavior and support of free speech in the U.S.
} 
We use data from Sierra Leone where a substantial education program was started in 2001. The program provided increased access to education for children who were primaryschool age, but did not benefit children who were older. We exploit the variation in access to the program generated by date of birth and the variation in resources between various districts of the country. We analyze whether an increase in schooling, triggered by the program, had an impact on women's attitudes towards matters that impact women's health and on attitudes regarding violence against women.

The household survey includes health-related questions on the acceptability of attitudes such as whether a wife is justified in refusing to have sex if the husband has a sexually transmitted disease, or whether a wife is justified in refusing sex when she is tired. It also includes questions gauging attitudes towards violence against women such as whether beating a wife is justified if she refused to have sex and whether the custom of female genital mutilation should be eradicated. We also employ questions that involve health behaviors such as the use of modern contraceptives and whether the person has been tested for AIDS, as well as the desired number of children.

We find that an increase in education changes women's preferences. Specifically, an additional year of schooling makes women more likely to declare that a wife is justified in refusing sex when she is tired or when the husband has a sexually transmitted disease. The same increase in schooling makes women more likely to disagree with the statement that wife beating is justified and more likely to declare that the practice of female genital mutilation should be stopped. These results indicate that education empowers women because an increase in education makes women more intolerant of practices that conflict with their well-being. An 
increase in education also reduces the number of desired children and increases the propensity to use modern contraception and to be tested for AIDS.

We can determine a respondent's literacy based on their ability to read a sentence as asked in the survey. We find that a switch from being illiterate to being literate is not the source of the change in attitudes. This is because an increase in education has no strong impact on women's literacy in Sierra Leone. Less than 40 percent of the individuals who have completed 1 to 3 years of schooling under the new program (post 2001) are literate or semiliterate. It is unclear through which particular mechanism education alters women's preferences. The impact could be due to a variety of factors ranging from the influence of teachers and peers as role models to socialization experiences in school. Nevertheless, an increase in education has a causal effect on preferences, much like the causal effect of education on health, although the exact mechanism remains also unclear in case of health outcomes (Mocan and Altindag 2012; Chou, Liu, Grossman and Joyce 2010; Cutler and LlerasMuney 2010; Grossman 2008).

Even though education empowers women so that they can voice preferences that are aligned with their own well-being, whether or not this would translate into actual behavioral change is unclear. This is because we also find that an increase in men's education, triggered by the program, does not alter men's attitudes regarding women's well-being. If men resist change, it is unclear if women's well-being would be improved in the short-run. At the same time, it is also possible that a change in women's preferences, detected in this paper, could facilitate a change in men's preferences over a period of time. Furthermore, much like the transmission of human capital from mothers to daughters reported by previous research, it is possible that the change in women's preferences could have an impact on their daughter's 
preferences. Regardless, these findings are potentially important for women's well-being to the extent that exogenous changes in the legal and political structure may not be effective in improving women's well-being if women themselves don't believe that such changes are necessary. 
Figure 1

Sierra Leone divided by districts in 2004

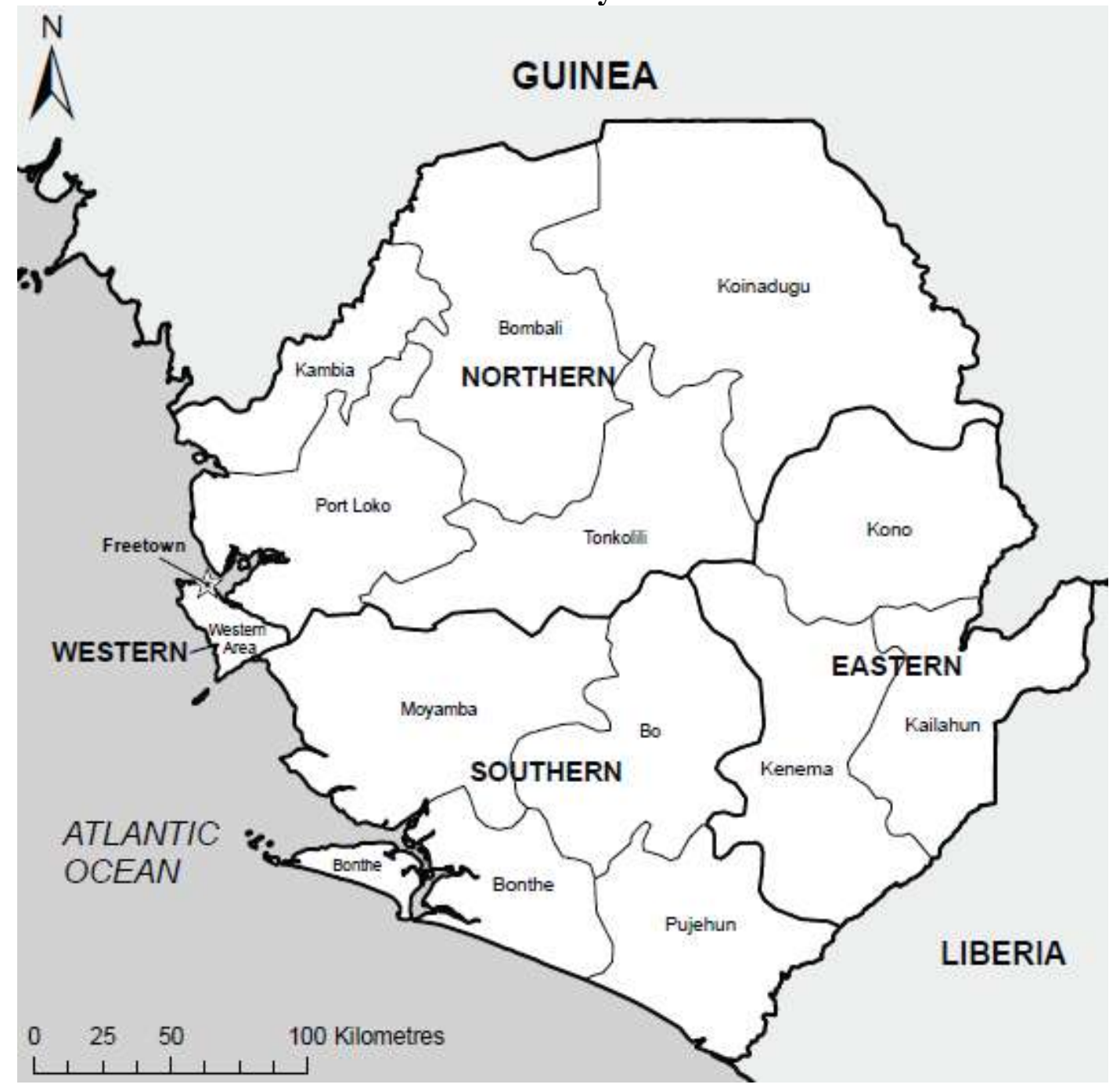

Notes: The fourteen districts are as follows: Eastern region consists of Kailahun, Kenema and Kono; Western region consists of the Western Urban Area (comprising mainly the capital Free Town) and the Western Rural Area; Northern region consists of Bombali, Kambia, Koinadagu, Port Loko and Tonkolili and the Southern region comprises Bo, Bonthe, Moyamba and Pujehun.

Source: Sierra Leone Demographic and Health Survey 2008 Report 
Summary Statistics: 2008 SLDHS Sample (Individual Level Data) - Females

\begin{tabular}{|c|c|c|c|c|}
\hline Variables & Variable Definition & All & $\begin{array}{c}\text { Treated } \\
\text { group } \\
\text { (Ages } \\
8-11 \text { in } \\
2001 \text { ) }\end{array}$ & $\begin{array}{c}\text { Control } \\
\text { group } \\
\text { (Ages } \\
\text { 15-21 in } \\
\text { 2001) }\end{array}$ \\
\hline & (1) & $\begin{array}{l}\text { Mean } \\
\text { (std) } \\
(2)\end{array}$ & $\begin{array}{l}\text { Mean } \\
\text { (std) } \\
(3)\end{array}$ & $\begin{array}{l}\text { Mean } \\
(\text { std }) \\
(4)\end{array}$ \\
\hline $\begin{array}{l}\text { Desired number of } \\
\text { children }\end{array}$ & Number of children desired & $\begin{array}{l}4.700 \\
(2.116)\end{array}$ & $\begin{array}{l}4.200 \\
(2.113)\end{array}$ & $\begin{array}{l}4.948 \\
(2.074)\end{array}$ \\
\hline $\begin{array}{l}\text { Modern } \\
\text { contraceptives }\end{array}$ & $\begin{array}{l}\text { Equals one if respondent uses modern } \\
\text { contraceptives, zero otherwise }\end{array}$ & 0.172 & 0.082 & 0.217 \\
\hline Tested for AIDS & $\begin{array}{l}\text { Equals one if respondent has ever been tested for } \\
\text { AIDS, zero otherwise }\end{array}$ & 0.131 & 0.054 & 0.170 \\
\hline $\begin{array}{l}\text { Wife justified in } \\
\text { refusing sex when } \\
\text { tired }\end{array}$ & $\begin{array}{l}\text { Equals one if respondent thinks a wife is justified in } \\
\text { refusing to have sex with her husband when she is } \\
\text { tired or not in the mood, zero otherwise }\end{array}$ & 0.559 & 0.499 & 0.589 \\
\hline $\begin{array}{l}\text { Wife justified in } \\
\text { refusing sex with } \\
\text { STD husband }\end{array}$ & $\begin{array}{l}\text { Equals one if respondent thinks a wife is justified in } \\
\text { refusing to have sex with a husband who has a } \\
\text { sexually transmitted disease, zero otherwise }\end{array}$ & 0.485 & 0.443 & 0.507 \\
\hline $\begin{array}{l}\text { Wife beating } \\
\text { justified in } \\
\text { refusing sex }\end{array}$ & $\begin{array}{l}\text { Equals one if respondent thinks that wife beating is } \\
\text { justified if she refuses to have sex with husband, zero } \\
\text { otherwise }\end{array}$ & 0.357 & 0.260 & 0.406 \\
\hline $\begin{array}{l}\text { Stop female } \\
\quad \text { genital mutilation }\end{array}$ & $\begin{array}{l}\text { Equals one if respondent thinks the practice of } \\
\text { female genital mutilation should be discontinued, } \\
\text { zero otherwise }\end{array}$ & 0.296 & 0.371 & 0.259 \\
\hline Schooling & Years of schooling completed & $\begin{array}{c}2.863 \\
(3.966)\end{array}$ & $\begin{array}{c}4.389 \\
(3.481)\end{array}$ & $\begin{array}{c}2.107 \\
(3.976)\end{array}$ \\
\hline Literate & $\begin{array}{l}\text { Equals one if respondent is able to read all of a } \\
\text { sentence, zero otherwise }\end{array}$ & 0.257 & 0.436 & 0.169 \\
\hline Literate2 & $\begin{array}{l}\text { Equals one if respondent is able to read all of a } \\
\text { sentence or some parts of a sentence, zero otherwise }\end{array}$ & 0.319 & 0.576 & 0.193 \\
\hline Age & Age in years & $\begin{array}{l}22.521 \\
(4.473)\end{array}$ & $\begin{array}{l}16.548 \\
(1.171)\end{array}$ & $\begin{array}{l}25.482 \\
(1.669)\end{array}$ \\
\hline Employed & Equals one if employed, zero otherwise & 0.662 & 0.458 & 0.762 \\
\hline Married & Equals one if married, zero otherwise & 0.558 & 0.209 & 0.731 \\
\hline Radio & $\begin{array}{l}\text { Equals one if respondent's household has a radio, } \\
\text { zero otherwise }\end{array}$ & 0.604 & 0.620 & 0.596 \\
\hline Fridge & $\begin{array}{l}\text { Equals one if respondent's household has a } \\
\text { refrigerator, zero otherwise }\end{array}$ & 0.083 & 0.104 & 0.073 \\
\hline TV & $\begin{array}{l}\text { Equals one if respondent's household has a } \\
\text { television, zero otherwise }\end{array}$ & 0.129 & 0.151 & 0.119 \\
\hline Urban & Equals one if resides in an urban area, zero otherwise & 0.383 & 0.451 & 0.349 \\
\hline Wealth 1 (poorest) & $\begin{array}{l}\text { Percentage of respondents within the first wealth } \\
\text { quintile }\end{array}$ & 0.177 & 0.148 & 0.192 \\
\hline
\end{tabular}


Table 1 (concluded)

\begin{tabular}{|c|c|c|c|c|}
\hline Wealth 2 (poorer) & $\begin{array}{l}\text { Percentage of respondents within the second wealth } \\
\text { quintile }\end{array}$ & 0.168 & 0.150 & 0.177 \\
\hline Wealth 3 (middle) & $\begin{array}{l}\text { Percentage of respondents within the third wealth } \\
\text { quintile }\end{array}$ & 0.195 & 0.182 & 0.202 \\
\hline Wealth 4 (richer) & $\begin{array}{l}\text { Percentage of respondents within the fourth wealth } \\
\text { quintile }\end{array}$ & 0.215 & 0.225 & 0.209 \\
\hline Wealth 5 (richest) & $\begin{array}{l}\text { Percentage of respondents within the fifth wealth } \\
\text { quintile }\end{array}$ & 0.245 & 0.295 & 0.220 \\
\hline \multicolumn{5}{|l|}{ Religion } \\
\hline Christian & $\begin{array}{l}\text { Equals one if belong to Christian religion, zero } \\
\text { otherwise }\end{array}$ & 0.216 & 0.258 & 0.195 \\
\hline Islam & Equals one if belong to Islam, zero otherwise & 0.773 & 0.730 & 0.794 \\
\hline Other religion & $\begin{array}{l}\text { Equals one if belong to another religion, zero } \\
\text { otherwise }\end{array}$ & 0.011 & 0.012 & 0.011 \\
\hline \multicolumn{5}{|l|}{ Ethnicity } \\
\hline Temne & $\begin{array}{l}\text { Equals one if belong to Temne ethnic group, zero } \\
\text { otherwise }\end{array}$ & 0.367 & 0.331 & 0.385 \\
\hline Mende & $\begin{array}{l}\text { Equals one if belong to Mende ethnic group, zero } \\
\text { otherwise }\end{array}$ & 0.307 & 0.329 & 0.296 \\
\hline Other ethnicity & $\begin{array}{l}\text { Equals one if belong to another ethnic group, zero } \\
\text { otherwise }\end{array}$ & 0.326 & 0.340 & 0.319 \\
\hline Observations & & 2,727 & 950 & 1,777 \\
\hline $\begin{array}{l}\text { Education Resources } \\
\text { (R) }\end{array}$ & $\begin{array}{l}\text { Funding for primary education in the district } \\
\text { measured as the logarithm of funding per } 100 \\
\text { teachers in } 2004 .(N=14)\end{array}$ & \multicolumn{3}{|c|}{ Mean $=1.294$, Std $=0.637$} \\
\hline
\end{tabular}

The descriptive statistics are calculated using sample weights from the SLDHS. 
Table 2

The Impact of the FPE Program on Schooling - Females

\begin{tabular}{|c|c|c|c|}
\hline & (1) & (2) & (3) \\
\hline & \multicolumn{3}{|c|}{$\begin{array}{l}\text { Dependent variable: } \\
\text { Years of Schooling }\end{array}$} \\
\hline FPE Cohort & $\begin{array}{l}0.521 * * \\
(0.238)\end{array}$ & & \\
\hline FPE Cohort * $\mathrm{R}$ & & $\begin{array}{c}0.706 * * * \\
(0.204)\end{array}$ & $\begin{array}{c}0.700 * * * \\
(0.236)\end{array}$ \\
\hline Christian & $\begin{array}{l}0.918 * * * \\
(0.212)\end{array}$ & $\begin{array}{c}0.905 * * * \\
(0.211)\end{array}$ & \\
\hline Temne & $\begin{array}{l}-0.294 \\
(0.245)\end{array}$ & $\begin{array}{l}-0.332 \\
(0.246)\end{array}$ & \\
\hline Mende & $\begin{array}{c}0.265 \\
(0.243)\end{array}$ & $\begin{array}{c}0.254 \\
(0.248)\end{array}$ & \\
\hline Urban & $\begin{array}{l}0.980 * * * \\
(0.208)\end{array}$ & $\begin{array}{c}0.925 * * * \\
(0.206)\end{array}$ & \\
\hline Married & $\begin{array}{c}-2.111 * * * \\
(0.219)\end{array}$ & $\begin{array}{c}-2.155 * * * \\
(0.222)\end{array}$ & \\
\hline Employed & $\begin{array}{l}-0.761 * * * \\
(0.166)\end{array}$ & $\begin{array}{c}-0.763 * * * \\
(0.172)\end{array}$ & \\
\hline Radio & $\begin{array}{c}0.323 * * \\
(0.139)\end{array}$ & $\begin{array}{l}0.302 * * \\
(0.138)\end{array}$ & \\
\hline Fridge & $\begin{array}{l}1.234 * * \\
(0.539)\end{array}$ & $\begin{array}{l}1.255^{* *} \\
(0.537)\end{array}$ & \\
\hline TV & $\begin{array}{l}0.611^{*} \\
(0.334)\end{array}$ & $\begin{array}{l}0.610^{*} \\
(0.325)\end{array}$ & \\
\hline Wealth 1 & $\begin{array}{r}-0.325^{*} \\
(0.188)\end{array}$ & $\begin{array}{l}-0.298 \\
(0.190)\end{array}$ & \\
\hline Wealth 2 & $\begin{array}{l}-0.019 \\
(0.185)\end{array}$ & $\begin{array}{l}-0.024 \\
(0.188)\end{array}$ & \\
\hline Wealth 4 & $\begin{array}{c}0.656^{* * * *} \\
(0.193)\end{array}$ & $\begin{array}{c}0.649 * * * \\
(0.196)\end{array}$ & \\
\hline Wealth 5 & $\begin{array}{c}1.535 * * * \\
(0.355)\end{array}$ & $\begin{array}{c}1.526 * * * \\
(0.359)\end{array}$ & \\
\hline District fixed-effects & Yes & Yes & Yes \\
\hline Year-of-birth fixed-effects & No & Yes & Yes \\
\hline Observations & 2,661 & 2,661 & 2,661 \\
\hline R-square & 0.445 & 0.452 & 0.281 \\
\hline
\end{tabular}

Standard errors in parentheses are clustered at the birth-year \& district level. Statistical levels of significance:

$*$ indicates $\mathrm{p}<0.1, * *$ indicates $\mathrm{p}<0.05, * * *$ indicates $\mathrm{p}<0.01$. The FPE cohort consists of those born during the period 1990 to 1993 . Those who are born between 1980 are 1985 in the control group. FPE Cohort *R is the product of the FPE Cohort dummy and the logarithm of district-level funding allocated for primary school education for every 100 teachers in 2004. Regressions are weighted by sample weights from the SLDHS. 
Table 3A

The Impact of Schooling on Preferences - Instrumental Variables Regressions - Females

\begin{tabular}{|c|c|c|c|c|c|c|c|}
\hline & (1) & (2) & (3) & (4) & (5) & (6) & (7) \\
\hline & \multicolumn{7}{|c|}{ Dependent variable: } \\
\hline & $\begin{array}{l}\text { Modern } \\
\text { contracep } \\
\text {-tives }\end{array}$ & $\begin{array}{l}\text { Tested } \\
\text { for AIDS }\end{array}$ & $\begin{array}{c}\text { Desired } \\
\text { number } \\
\text { of } \\
\text { children }\end{array}$ & $\begin{array}{l}\text { Wife } \\
\text { justified in } \\
\text { refusing } \\
\text { sex when } \\
\text { tired }\end{array}$ & $\begin{array}{l}\text { Wife } \\
\text { justified } \\
\text { in } \\
\text { refusing } \\
\text { sex with } \\
\text { STD } \\
\text { husband }\end{array}$ & $\begin{array}{l}\text { Wife } \\
\text { beating } \\
\text { justified } \\
\text { in } \\
\text { refusing } \\
\text { sex }\end{array}$ & $\begin{array}{c}\text { Stop } \\
\text { Female } \\
\text { Genital } \\
\text { Mutilation }\end{array}$ \\
\hline Schooling & $\begin{array}{c}0.118 * * \\
(0.053)\end{array}$ & $\begin{array}{c}0.112 * * * \\
(0.036)\end{array}$ & $\begin{array}{c}-0.340^{*} \\
(0.183)\end{array}$ & $\begin{array}{c}0.043 \\
(0.043)\end{array}$ & $\begin{array}{c}0.107 * * \\
(0.054)\end{array}$ & $\begin{array}{c}-0.095^{*} \\
(0.056)\end{array}$ & $\begin{array}{l}0.088^{*} \\
(0.047)\end{array}$ \\
\hline Christian & $\begin{array}{l}-0.033 \\
(0.058)\end{array}$ & $\begin{array}{l}-0.032 \\
(0.042)\end{array}$ & $\begin{array}{l}-0.030 \\
(0.204)\end{array}$ & $\begin{array}{l}-0.036 \\
(0.050)\end{array}$ & $\begin{array}{l}-0.079 \\
(0.066)\end{array}$ & $\begin{array}{c}0.072 \\
(0.060)\end{array}$ & $\begin{array}{c}0.085 \\
(0.054)\end{array}$ \\
\hline Temne & $\begin{array}{c}0.037 \\
(0.041)\end{array}$ & $\begin{array}{l}0.054^{*} \\
(0.031)\end{array}$ & $\begin{array}{c}0.036 \\
(0.140)\end{array}$ & $\begin{array}{c}0.014 \\
(0.035)\end{array}$ & $\begin{array}{c}0.083 * * \\
(0.040)\end{array}$ & $\begin{array}{c}0.031 \\
(0.042)\end{array}$ & $\begin{array}{l}-0.014 \\
(0.041)\end{array}$ \\
\hline Mende & $\begin{array}{l}-0.054 \\
(0.042)\end{array}$ & $\begin{array}{c}0.039 \\
(0.036)\end{array}$ & $\begin{array}{c}0.011 \\
(0.176)\end{array}$ & $\begin{array}{c}-0.111 * * * \\
(0.037)\end{array}$ & $\begin{array}{l}-0.053 \\
(0.049)\end{array}$ & $\begin{array}{l}-0.034 \\
(0.041)\end{array}$ & $\begin{array}{l}-0.038 \\
(0.042)\end{array}$ \\
\hline Urban & $\begin{array}{c}-0.096^{*} \\
(0.053)\end{array}$ & $\begin{array}{c}-0.068^{*} \\
(0.040)\end{array}$ & $\begin{array}{c}0.080 \\
(0.248)\end{array}$ & $\begin{array}{l}-0.046 \\
(0.051)\end{array}$ & $\begin{array}{l}-0.090 \\
(0.066)\end{array}$ & $\begin{array}{c}0.063 \\
(0.066)\end{array}$ & $\begin{array}{c}0.028 \\
(0.059)\end{array}$ \\
\hline Married & $\begin{array}{c}0.153 \\
(0.115)\end{array}$ & $\begin{array}{c}0.238 * * * \\
(0.083)\end{array}$ & $\begin{array}{l}-0.173 \\
(0.421)\end{array}$ & $\begin{array}{c}0.052 \\
(0.102)\end{array}$ & $\begin{array}{c}0.168 \\
(0.121)\end{array}$ & $\begin{array}{l}-0.090 \\
(0.122)\end{array}$ & $\begin{array}{c}0.100 \\
(0.105)\end{array}$ \\
\hline Employed & $\begin{array}{c}0.111 * * \\
(0.048)\end{array}$ & $\begin{array}{c}0.079 * * \\
(0.033)\end{array}$ & $\begin{array}{l}-0.095 \\
(0.184)\end{array}$ & $\begin{array}{c}-0.028 \\
(0.042)\end{array}$ & $\begin{array}{c}0.030 \\
(0.052)\end{array}$ & $\begin{array}{l}-0.034 \\
(0.050)\end{array}$ & $\begin{array}{c}0.033 \\
(0.039)\end{array}$ \\
\hline Radio & $\begin{array}{c}-0.045^{* *} \\
(0.022)\end{array}$ & $\begin{array}{l}-0.023 \\
(0.022)\end{array}$ & $\begin{array}{c}0.051 \\
(0.123)\end{array}$ & $\begin{array}{c}0.024 \\
(0.026)\end{array}$ & $\begin{array}{l}-0.020 \\
(0.031)\end{array}$ & $\begin{array}{c}0.035 \\
(0.031)\end{array}$ & $\begin{array}{l}-0.041 \\
(0.028)\end{array}$ \\
\hline Fridge & $\begin{array}{c}-0.154^{*} \\
(0.085)\end{array}$ & $\begin{array}{l}-0.102 \\
(0.062)\end{array}$ & $\begin{array}{c}0.279 \\
(0.291)\end{array}$ & $\begin{array}{c}-0.022 \\
(0.061)\end{array}$ & $\begin{array}{l}-0.076 \\
(0.091)\end{array}$ & $\begin{array}{c}0.065 \\
(0.095)\end{array}$ & $\begin{array}{l}-0.016 \\
(0.080)\end{array}$ \\
\hline TV & $\begin{array}{c}0.021 \\
(0.061)\end{array}$ & $\begin{array}{l}-0.063 \\
(0.053)\end{array}$ & $\begin{array}{c}0.058 \\
(0.209)\end{array}$ & $\begin{array}{c}0.032 \\
(0.068)\end{array}$ & $\begin{array}{l}-0.076 \\
(0.064)\end{array}$ & $\begin{array}{l}-0.014 \\
(0.059)\end{array}$ & $\begin{array}{l}-0.053 \\
(0.052)\end{array}$ \\
\hline Wealth 1 & $\begin{array}{c}0.006 \\
(0.032)\end{array}$ & $\begin{array}{c}0.008 \\
(0.032)\end{array}$ & $\begin{array}{c}0.093 \\
(0.179)\end{array}$ & $\begin{array}{c}0.071 * * \\
(0.036)\end{array}$ & $\begin{array}{c}0.063 \\
(0.044)\end{array}$ & $\begin{array}{l}-0.038 \\
(0.044)\end{array}$ & $\begin{array}{l}-0.028 \\
(0.032)\end{array}$ \\
\hline Wealth 2 & $\begin{array}{l}-0.012 \\
(0.026)\end{array}$ & $\begin{array}{c}0.019 \\
(0.027)\end{array}$ & $\begin{array}{c}0.262 \\
(0.191)\end{array}$ & $\begin{array}{c}0.059 \\
(0.041)\end{array}$ & $\begin{array}{c}0.034 \\
(0.042)\end{array}$ & $\begin{array}{c}0.033 \\
(0.038)\end{array}$ & $\begin{array}{l}-0.035 \\
(0.027)\end{array}$ \\
\hline Wealth 4 & $\begin{array}{l}-0.042 \\
(0.038)\end{array}$ & $\begin{array}{l}-0.050 \\
(0.039)\end{array}$ & $\begin{array}{c}0.044 \\
(0.194)\end{array}$ & $\begin{array}{c}0.007 \\
(0.043)\end{array}$ & $\begin{array}{l}-0.061 \\
(0.053)\end{array}$ & $\begin{array}{l}-0.023 \\
(0.054)\end{array}$ & $\begin{array}{l}-0.057 \\
(0.052)\end{array}$ \\
\hline Wealth 5 & $\begin{array}{l}-0.091 \\
(0.090)\end{array}$ & $\begin{array}{l}-0.117 \\
(0.076)\end{array}$ & $\begin{array}{c}0.095 \\
(0.350)\end{array}$ & $\begin{array}{l}-0.021 \\
(0.086)\end{array}$ & $\begin{array}{l}-0.123 \\
(0.108)\end{array}$ & $\begin{array}{c}0.047 \\
(0.101)\end{array}$ & $\begin{array}{l}-0.114 \\
(0.092)\end{array}$ \\
\hline District FE & Yes & Yes & Yes & Yes & Yes & Yes & Yes \\
\hline Birth year FE & Yes & Yes & Yes & Yes & Yes & Yes & Yes \\
\hline First stage (F-stat.) & 12.041 & 11.362 & 12.041 & 12.819 & 12.221 & 11.762 & 12.041 \\
\hline Observations & 2,661 & 2,615 & 2,661 & 2,624 & 2,640 & 2,655 & 2,661 \\
\hline
\end{tabular}

Notes: Standard errors in parentheses are clustered at the birth-year*district level. Statistical levels of significance are: * indicates $\mathrm{p}<0.1$, $* *$ indicates $\mathrm{p}<0.05, * * *$ indicates $\mathrm{p}<0.01$. The sample comprises the FPE cohort (those born during the period 1990 to 1993 ) and those born during the period 1980 to 1985. Instrument: interaction of FPE cohort and $R$, where $R$ is calculated as the logarithm of total funding allocated for primary school education for every 100 teachers in each district in 2004. Regressions are weighted by sample weight from the SLDHS. 
Table 3B

The Impact of Schooling on Preferences - Instrumental Variables Regressions - Females

(1)

(2)

(3)

(4)

(5)

(6)

(7)

Dependent variable

\begin{tabular}{lc|c|c|c|c|c|c} 
& $\begin{array}{c}\text { Modern } \\
\text { contracep } \\
\text {-tives }\end{array}$ & $\begin{array}{c}\text { Tested } \\
\text { for AIDS }\end{array}$ & $\begin{array}{c}\text { Desired } \\
\text { number } \\
\text { of } \\
\text { children }\end{array}$ & $\begin{array}{c}\text { Wife } \\
\text { justified } \\
\text { in } \\
\text { refusing } \\
\text { sex } \\
\text { when } \\
\text { tired }\end{array}$ & $\begin{array}{c}\text { Wife } \\
\text { justified } \\
\text { in } \\
\text { refusing } \\
\text { sex with } \\
\text { STD } \\
\text { husband }\end{array}$ & $\begin{array}{c}\text { Wife } \\
\text { beating } \\
\text { justified } \\
\text { in } \\
\text { refusing } \\
\text { sex }\end{array}$ & $\begin{array}{c}\text { Stop } \\
\text { Female } \\
\text { Genital } \\
\text { Mutilati- } \\
\text { on }\end{array}$ \\
Schooling & & & & & $0.111^{*}$ & $-0.106^{*}$ & $0.096^{*}$ \\
& $0.137^{* *}$ & $0.130^{* * *}$ & $-0.357^{*}$ & 0.053 & $0.059)$ & $(0.050)$ \\
\hline District FE & $(0.065)$ & $(0.043)$ & $(0.204)$ & $(0.051)$ & $(0.067)$ & $(0.059)$ \\
Birth year FE & Yes & Yes & Yes & Yes & Yes & Yes & Yes \\
First stage (F-stat.) & 7.561 & 7.149 & 7.561 & 7.783 & 7.439 & 7.463 & 7.561 \\
Observations & 2,721 & 2,675 & 2,721 & 2,678 & 2,694 & 2,710 & 2,721 \\
\hline
\end{tabular}

Notes: Standard errors in parentheses are clustered at the birth-year*district level. Statistical levels of significance are: * indicates $\mathrm{p}<0.1$, $* *$ indicates $\mathrm{p}<0.05, * * *$ indicates $\mathrm{p}<0.01$. The sample comprises the FPE cohort (those born during the period 1990 to 1993 ) and those born during the period 1980 to 1985. Instrument: interaction of FPE cohort and $R$, where $R$ is the logarithm of total funding allocated for primary school education for every 100 teachers in each district in 2004. Regressions are weighted by sample weight from the SLDHS. 
Table 4

The Impact of Literacy on Preferences - OLS Regressions - Females

\begin{tabular}{|c|c|c|c|c|c|c|c|}
\hline & (1) & $(2)$ & (3) & (4) & $(5)$ & (6) & (7) \\
\hline & \multicolumn{7}{|c|}{ Dependent variable: } \\
\hline & $\begin{array}{l}\text { Modern } \\
\text { contracep- } \\
\text { tives }\end{array}$ & $\begin{array}{c}\text { Tested } \\
\text { for AIDS }\end{array}$ & $\begin{array}{c}\text { Desired } \\
\text { number of } \\
\text { children }\end{array}$ & $\begin{array}{l}\text { Wife } \\
\text { justified in } \\
\text { refusing } \\
\text { sex when } \\
\text { tired }\end{array}$ & $\begin{array}{c}\text { Wife } \\
\text { justified } \\
\text { in } \\
\text { refusing } \\
\text { sex with } \\
\text { STD } \\
\text { husband }\end{array}$ & $\begin{array}{l}\text { Wife } \\
\text { beating } \\
\text { justified in } \\
\text { refusing } \\
\text { sex }\end{array}$ & $\begin{array}{c}\text { Stop } \\
\text { Female } \\
\text { Genital } \\
\text { Mutilati- } \\
\text { on }\end{array}$ \\
\hline Literate & $\begin{array}{c}0.165 * * * \\
(0.030)\end{array}$ & $\begin{array}{c}0.105^{* * *} * \\
(0.025)\end{array}$ & $\begin{array}{c}-0.573 * * * \\
(0.099)\end{array}$ & $\begin{array}{c}0.114 * * * \\
(0.033)\end{array}$ & $\begin{array}{c}0.107 * * * \\
(0.029)\end{array}$ & $\begin{array}{c}-0.097 * * * \\
(0.029)\end{array}$ & $\begin{array}{c}0.164 * * * \\
(0.030)\end{array}$ \\
\hline Christian & $\begin{array}{c}0.056^{* *} \\
(0.024)\end{array}$ & $\begin{array}{c}0.056 * * * \\
(0.015)\end{array}$ & $\begin{array}{c}-0.286 * * * \\
(0.085)\end{array}$ & $\begin{array}{l}-0.012 \\
(0.025)\end{array}$ & $\begin{array}{c}0.005 \\
(0.033)\end{array}$ & $\begin{array}{c}-0.004 \\
(0.024)\end{array}$ & $\begin{array}{c}0.151 * * * * \\
(0.027)\end{array}$ \\
\hline Temne & $\begin{array}{c}0.007 \\
(0.027)\end{array}$ & $\begin{array}{c}0.024 \\
(0.021)\end{array}$ & $\begin{array}{c}0.108 \\
(0.117)\end{array}$ & $\begin{array}{c}0.003 \\
(0.032)\end{array}$ & $\begin{array}{c}0.051 \\
(0.032)\end{array}$ & $\begin{array}{c}0.058 * * \\
(0.030)\end{array}$ & $\begin{array}{c}-0.031 \\
(0.036)\end{array}$ \\
\hline Mende & $\begin{array}{l}-0.019 \\
(0.029)\end{array}$ & $\begin{array}{c}0.074 * * * \\
(0.029)\end{array}$ & $\begin{array}{l}-0.081 \\
(0.137)\end{array}$ & $\begin{array}{c}-0.103 * * * \\
(0.036)\end{array}$ & $\begin{array}{l}-0.031 \\
(0.042)\end{array}$ & $\begin{array}{c}-0.056^{*} \\
(0.032)\end{array}$ & $\begin{array}{c}-0.012 \\
(0.037)\end{array}$ \\
\hline Urban & $\begin{array}{l}-0.003 \\
(0.021)\end{array}$ & $\begin{array}{c}0.020 \\
(0.018)\end{array}$ & $\begin{array}{l}-0.174 \\
(0.135)\end{array}$ & $\begin{array}{l}-0.022 \\
(0.032)\end{array}$ & $\begin{array}{c}-0.001 \\
(0.033)\end{array}$ & $\begin{array}{l}-0.015 \\
(0.037)\end{array}$ & $\begin{array}{c}0.094 * * * \\
(0.033)\end{array}$ \\
\hline Married & $\begin{array}{c}-0.069 * * * \\
(0.023)\end{array}$ & $\begin{array}{c}0.022 \\
(0.020)\end{array}$ & $\begin{array}{c}0.422 * * * \\
(0.102)\end{array}$ & $\begin{array}{l}-0.021 \\
(0.029)\end{array}$ & $\begin{array}{c}-0.047^{*} \\
(0.026)\end{array}$ & $\begin{array}{c}0.093 * * * \\
(0.028)\end{array}$ & $\begin{array}{c}-0.059 * * * \\
(0.022)\end{array}$ \\
\hline Employed & $\begin{array}{c}0.040^{* *} \\
(0.018)\end{array}$ & $\begin{array}{c}0.007 \\
(0.016)\end{array}$ & $\begin{array}{c}0.112 \\
(0.106)\end{array}$ & $\begin{array}{c}-0.048^{*} \\
(0.027)\end{array}$ & $\begin{array}{l}-0.039 \\
(0.032)\end{array}$ & $\begin{array}{c}0.031 \\
(0.024)\end{array}$ & $\begin{array}{c}-0.014 \\
(0.024)\end{array}$ \\
\hline Radio & $\begin{array}{l}-0.017 \\
(0.016)\end{array}$ & $\begin{array}{c}0.004 \\
(0.015)\end{array}$ & $\begin{array}{l}-0.036 \\
(0.110)\end{array}$ & $\begin{array}{c}0.029 \\
(0.023)\end{array}$ & $\begin{array}{c}0.007 \\
(0.026)\end{array}$ & $\begin{array}{c}0.007 \\
(0.024)\end{array}$ & $\begin{array}{l}-0.023 \\
(0.023)\end{array}$ \\
\hline Fridge & $\begin{array}{l}-0.023 \\
(0.036)\end{array}$ & $\begin{array}{c}0.031 \\
(0.034)\end{array}$ & $\begin{array}{l}-0.079 \\
(0.134)\end{array}$ & $\begin{array}{c}0.015 \\
(0.043)\end{array}$ & $\begin{array}{c}0.037 \\
(0.050)\end{array}$ & $\begin{array}{l}-0.041 \\
(0.032)\end{array}$ & $\begin{array}{c}0.074 \\
(0.046)\end{array}$ \\
\hline TV & $\begin{array}{c}0.081 * * \\
(0.037)\end{array}$ & $\begin{array}{l}-0.006 \\
(0.031)\end{array}$ & $\begin{array}{l}-0.125 \\
(0.188)\end{array}$ & $\begin{array}{c}0.061 \\
(0.062)\end{array}$ & $\begin{array}{l}-0.009 \\
(0.061)\end{array}$ & $\begin{array}{c}-0.072 * \\
(0.043)\end{array}$ & $\begin{array}{l}-0.006 \\
(0.042)\end{array}$ \\
\hline Wealth 1 & $\begin{array}{l}-0.030 \\
(0.023)\end{array}$ & $\begin{array}{l}-0.029 \\
(0.023)\end{array}$ & $\begin{array}{c}0.177 \\
(0.167)\end{array}$ & $\begin{array}{l}0.059^{*} \\
(0.035)\end{array}$ & $\begin{array}{c}0.031 \\
(0.038)\end{array}$ & $\begin{array}{l}-0.009 \\
(0.039)\end{array}$ & $\begin{array}{c}-0.055^{* *} \\
(0.027)\end{array}$ \\
\hline Wealth 2 & $\begin{array}{l}-0.012 \\
(0.023)\end{array}$ & $\begin{array}{c}0.021 \\
(0.022)\end{array}$ & $\begin{array}{c}0.230 \\
(0.186)\end{array}$ & $\begin{array}{c}0.060 \\
(0.041)\end{array}$ & $\begin{array}{c}0.037 \\
(0.041)\end{array}$ & $\begin{array}{c}0.029 \\
(0.036)\end{array}$ & $\begin{array}{l}-0.035 \\
(0.028)\end{array}$ \\
\hline Wealth 4 & $\begin{array}{c}0.022 \\
(0.020)\end{array}$ & $\begin{array}{c}0.018 \\
(0.020)\end{array}$ & $\begin{array}{l}-0.168 \\
(0.150)\end{array}$ & $\begin{array}{c}0.029 \\
(0.035)\end{array}$ & $\begin{array}{c}0.002 \\
(0.039)\end{array}$ & $\begin{array}{c}-0.079 * * \\
(0.035)\end{array}$ & $\begin{array}{l}-0.009 \\
(0.038)\end{array}$ \\
\hline Wealth 5 & $\begin{array}{l}0.061 * \\
(0.032)\end{array}$ & $\begin{array}{c}0.044 \\
(0.036)\end{array}$ & $\begin{array}{l}-0.344 * \\
(0.192)\end{array}$ & $\begin{array}{c}0.025 \\
(0.056)\end{array}$ & $\begin{array}{c}0.023 \\
(0.052)\end{array}$ & $\begin{array}{c}-0.085^{*} \\
(0.048)\end{array}$ & $\begin{array}{l}-0.008 \\
(0.050)\end{array}$ \\
\hline District FE & Yes & Yes & Yes & Yes & Yes & Yes & Yes \\
\hline Birth year FE & Yes & Yes & Yes & Yes & Yes & Yes & Yes \\
\hline Observations & 2,637 & 2,591 & 2,637 & 2,602 & 2,617 & 2,631 & 2,637 \\
\hline
\end{tabular}

Notes: Standard errors in parentheses are clustered at the birth-year*district level. Statistical levels of significance are: * indicates $\mathrm{p}<0.1$, ** indicates $\mathrm{p}<0.05, * * *$ indicates $\mathrm{p}<0.01$. The sample comprises the FPE cohort (those born during the period 1990 to 1993) and those born during the period 1980 to 1985 . Literate is a dummy variable to indicate literacy of the person. Regressions are weighted by sample weight from the SLDHS. 
Table 5

Percentage of Literate and Semi-literate Females by Completed Schooling and Exposure to the FPE Program.

\section{Control Group Treated Group}

(Not exposed to the FPE (Exposed to the FPE

Program)

Program)

\begin{tabular}{lcccc}
\hline Education & $\begin{array}{c}\text { Literate } \\
(\%)\end{array}$ & $\begin{array}{c}\text { Literate or } \\
\text { Semi-literate } \\
(\%)\end{array}$ & $\begin{array}{c}\text { Literate } \\
(\%)\end{array}$ & $\begin{array}{c}\text { Literate or } \\
\text { Semi-literate } \\
(\%)\end{array}$ \\
\hline 0 years & 0 & 0.8 & 0 & 0 \\
1 to 3 years & 0 & 8.3 & 7.7 & 38.5 \\
4 to 6 years & 5.6 & 30.4 & 29.6 & 74.7 \\
Greater than 7 years & 100 & 100 & 100 & 100 \\
\hline
\end{tabular}




\begin{tabular}{|c|c|c|c|c|}
\hline Variables & Variable Definition & All & $\begin{array}{c}\text { Treated } \\
\text { group } \\
\text { (Ages } \\
\text { 8-11 in } \\
2001 \text { ) }\end{array}$ & $\begin{array}{c}\text { Control } \\
\text { group } \\
\text { (Ages 15- } \\
21 \text { in } \\
2001 \text { ) }\end{array}$ \\
\hline & (1) & $\begin{array}{l}\text { Mean } \\
(\text { std) } \\
(2)\end{array}$ & $\begin{array}{l}\text { Mean } \\
\text { (std) } \\
(3)\end{array}$ & $\begin{array}{c}\text { Mean } \\
(\text { std }) \\
(4)\end{array}$ \\
\hline $\begin{array}{l}\text { Desired number of } \\
\text { children }\end{array}$ & Number of children desired & $\begin{array}{l}4.438 \\
(2.938)\end{array}$ & $\begin{array}{l}4.122 \\
(2.731)\end{array}$ & $\begin{array}{c}4.687 \\
(3.070)\end{array}$ \\
\hline $\begin{array}{l}\text { Modern } \\
\text { contraceptives }\end{array}$ & $\begin{array}{l}\text { Equals one if respondent uses modern } \\
\text { contraceptives, zero otherwise }\end{array}$ & 0.228 & 0.072 & 0.350 \\
\hline Tested for AIDS & $\begin{array}{l}\text { Equals one if respondent has ever been tested for the } \\
\text { AIDS virus, zero otherwise }\end{array}$ & 0.070 & 0.024 & 0.101 \\
\hline $\begin{array}{l}\text { Wife justified in } \\
\text { refusing sex when } \\
\text { tired }\end{array}$ & $\begin{array}{l}\text { Equals one if respondent thinks a wife is justified in } \\
\text { refusing to have sex with her husband when she is } \\
\text { tired or not in the mood, zero otherwise }\end{array}$ & 0.683 & 0.616 & 0.736 \\
\hline $\begin{array}{l}\text { Wife justified in } \\
\text { refusing sex with } \\
\text { STD husband }\end{array}$ & $\begin{array}{l}\text { Equals one if respondent thinks a wife is justified in } \\
\text { refusing to have sex with a husband having an STD, } \\
\text { zero otherwise }\end{array}$ & 0.578 & 0.521 & 0.623 \\
\hline $\begin{array}{l}\text { Wife beating } \\
\text { justified } \\
\text { in refusing sex }\end{array}$ & $\begin{array}{l}\text { Equals one if respondent thinks that wife beating is } \\
\text { justified if she refuses to have sex with husband, zero } \\
\text { otherwise }\end{array}$ & 0.231 & 0.239 & 0.225 \\
\hline $\begin{array}{l}\text { Stop female } \\
\text { genital mutilation }\end{array}$ & $\begin{array}{l}\text { Equals one if respondent thinks the practice of } \\
\text { female genital mutilation should be } \\
\text { DISCONTINUED, zero otherwise }\end{array}$ & 0.375 & 0.338 & 0.404 \\
\hline Schooling & Years of schooling completed & $\begin{array}{c}4.956 \\
(4.678)\end{array}$ & $\begin{array}{l}5.283 \\
(3.547)\end{array}$ & $\begin{array}{c}4.700 \\
(5.392)\end{array}$ \\
\hline Literate & $\begin{array}{l}\text { Equals one if respondent is able to read all of the } \\
\text { sentence, zero otherwise }\end{array}$ & 0.471 & 0.572 & 0.392 \\
\hline Literate2 & $\begin{array}{l}\text { Equals one if respondent is able to read all of the } \\
\text { sentence or some parts of the sentence, zero } \\
\text { otherwise }\end{array}$ & 0.566 & 0.730 & 0.437 \\
\hline Age & Age in years & $\begin{array}{l}21.582 \\
(4.733)\end{array}$ & $\begin{array}{l}16.555 \\
(1.171)\end{array}$ & $\begin{array}{l}25.528 \\
(1.858)\end{array}$ \\
\hline Employed & Equals one if employed, zero otherwise & 0.705 & 0.525 & 0.845 \\
\hline Married & Equals one if married, zero otherwise & 0.237 & 0.005 & 0.419 \\
\hline Radio & $\begin{array}{l}\text { Equals one if respondent's household has a radio, } \\
\text { zero otherwise }\end{array}$ & 0.653 & 0.632 & 0.669 \\
\hline Fridge & $\begin{array}{l}\text { Equals one if respondent's household has a } \\
\text { refrigerator, zero otherwise }\end{array}$ & 0.101 & 0.112 & 0.092 \\
\hline TV & $\begin{array}{l}\text { Equals one if respondent's household has a } \\
\text { television, zero otherwise }\end{array}$ & 0.160 & 0.144 & 0.172 \\
\hline Urban & Equals one if resides in an urban area, zero otherwise & 0.440 & 0.472 & 0.414 \\
\hline Wealth 1(poorest) & $\begin{array}{l}\text { Percentage of respondents within the first wealth } \\
\text { quintile }\end{array}$ & 0.166 & 0.166 & 0.167 \\
\hline
\end{tabular}


Table 6 (Concluded)

\begin{tabular}{|c|c|c|c|c|}
\hline Wealth 2 (poorer) & $\begin{array}{l}\text { Percentage of respondents within the second wealth } \\
\text { quintile }\end{array}$ & 0.160 & 0.153 & 0.166 \\
\hline Wealth 3 (middle) & $\begin{array}{l}\text { Percentage of respondents within the third wealth } \\
\text { quintile }\end{array}$ & 0.160 & 0.148 & 0.169 \\
\hline Wealth 4 (richer) & $\begin{array}{l}\text { Percentage of respondents within the fourth wealth } \\
\text { quintile }\end{array}$ & 0.209 & 0.219 & 0.201 \\
\hline Wealth 5 (richest) & $\begin{array}{l}\text { Percentage of respondents within the fifth wealth } \\
\text { quintile }\end{array}$ & 0.304 & 0.314 & 0.297 \\
\hline \multicolumn{5}{|l|}{ Religion } \\
\hline Christian & $\begin{array}{l}\text { Equals one if belong to Christian religion, zero } \\
\text { otherwise }\end{array}$ & 0.223 & 0.208 & 0.234 \\
\hline Islam & Equals one if belong to Islam, zero otherwise & 0.776 & 0.792 & 0.763 \\
\hline Other religion & $\begin{array}{l}\text { Equals one if belong to another religion, zero } \\
\text { otherwise }\end{array}$ & 0.001 & 0.000 & 0.003 \\
\hline \multicolumn{5}{|l|}{ Ethnicity } \\
\hline Temne & $\begin{array}{l}\text { Equals one if belong to Temne ethnic group, zero } \\
\text { otherwise }\end{array}$ & 0.386 & 0.354 & 0.411 \\
\hline Mende & $\begin{array}{l}\text { Equals one if belong to Mende ethnic group, zero } \\
\text { otherwise }\end{array}$ & 0.383 & 0.278 & 0.287 \\
\hline Other ethnicity & $\begin{array}{l}\text { Equals one if belong to another ethnic group, zero } \\
\text { otherwise }\end{array}$ & 0.331 & 0.368 & 0.302 \\
\hline Observations & & 896 & 404 & 492 \\
\hline
\end{tabular}

The descriptive statistics are calculated using sample weights from the SLDHS. 
Table 7

The Impact of Schooling on Preferences - Instrumental Variables Regressions - Males

\begin{tabular}{|c|c|c|c|c|c|c|c|}
\hline & (1) & (2) & (3) & (4) & (5) & (6) & (7) \\
\hline & \multicolumn{7}{|c|}{ Dependent variables } \\
\hline & $\begin{array}{c}\text { Modern } \\
\text { contracep } \\
\text {-tives }\end{array}$ & $\begin{array}{l}\text { Tested for } \\
\text { AIDS }\end{array}$ & $\begin{array}{c}\text { Desired } \\
\text { number } \\
\text { of } \\
\text { children }\end{array}$ & $\begin{array}{c}\text { Wife } \\
\text { justified } \\
\text { in } \\
\text { refusing } \\
\text { sex } \\
\text { when } \\
\text { tired }\end{array}$ & $\begin{array}{c}\text { Wife } \\
\text { justified } \\
\text { in } \\
\text { refusing } \\
\text { sex with } \\
\text { STD } \\
\text { husband }\end{array}$ & $\begin{array}{l}\text { Wife } \\
\text { beating } \\
\text { justified } \\
\text { in } \\
\text { refusing } \\
\text { sex }\end{array}$ & $\begin{array}{c}\text { Stop } \\
\text { Female } \\
\text { Genital } \\
\text { Mutilati } \\
\text {-on }\end{array}$ \\
\hline Schooling & $\begin{array}{c}0.069 * * * \\
(0.026)\end{array}$ & $\begin{array}{c}0.048 * * * \\
(0.015)\end{array}$ & $\begin{array}{l}-0.131 \\
(0.216)\end{array}$ & $\begin{array}{l}-0.037 \\
(0.056)\end{array}$ & $\begin{array}{c}-0.059 \\
(0.049)\end{array}$ & $\begin{array}{l}-0.024 \\
(0.039)\end{array}$ & $\begin{array}{c}0.011 \\
(0.031)\end{array}$ \\
\hline Christian & $\begin{array}{c}0.053 \\
(0.049)\end{array}$ & $\begin{array}{c}-0.003 \\
(0.035)\end{array}$ & $\begin{array}{l}-0.005 \\
(0.312)\end{array}$ & $\begin{array}{c}0.097 \\
(0.075)\end{array}$ & $\begin{array}{c}0.170 * * \\
(0.076)\end{array}$ & $\begin{array}{l}-0.017 \\
(0.057)\end{array}$ & $\begin{array}{c}0.141 * * \\
(0.059)\end{array}$ \\
\hline Temne & $\begin{array}{l}-0.008 \\
(0.047)\end{array}$ & $\begin{array}{c}-0.022 \\
(0.027)\end{array}$ & $\begin{array}{c}0.418 \\
(0.256)\end{array}$ & $\begin{array}{c}-0.058 \\
(0.050)\end{array}$ & $\begin{array}{l}0.105^{*} \\
(0.056)\end{array}$ & $\begin{array}{c}0.016 \\
(0.045)\end{array}$ & $\begin{array}{l}-0.019 \\
(0.054)\end{array}$ \\
\hline Mende & $\begin{array}{c}0.022 \\
(0.055)\end{array}$ & $\begin{array}{l}-0.040 \\
(0.040)\end{array}$ & $\begin{array}{c}0.137 \\
(0.213)\end{array}$ & $\begin{array}{l}-0.069 \\
(0.045)\end{array}$ & $\begin{array}{l}-0.025 \\
(0.054)\end{array}$ & $\begin{array}{c}0.048 \\
(0.043)\end{array}$ & $\begin{array}{l}-0.028 \\
(0.055)\end{array}$ \\
\hline Urban & $\begin{array}{l}-0.004 \\
(0.065)\end{array}$ & $\begin{array}{c}-0.072 \\
(0.045)\end{array}$ & $\begin{array}{c}0.528 \\
(0.390)\end{array}$ & $\begin{array}{c}0.000 \\
(0.122)\end{array}$ & $\begin{array}{c}0.060 \\
(0.109)\end{array}$ & $\begin{array}{c}0.082 \\
(0.079)\end{array}$ & $\begin{array}{c}0.052 \\
(0.075)\end{array}$ \\
\hline Married & $\begin{array}{c}-0.018 \\
(0.063)\end{array}$ & $\begin{array}{l}0.065 * \\
(0.038)\end{array}$ & $\begin{array}{c}0.721 \\
(0.473)\end{array}$ & $\begin{array}{l}-0.023 \\
(0.117)\end{array}$ & $\begin{array}{l}-0.112 \\
(0.113)\end{array}$ & $\begin{array}{l}-0.112 \\
(0.090)\end{array}$ & $\begin{array}{l}-0.036 \\
(0.067)\end{array}$ \\
\hline Employed & $\begin{array}{c}0.178^{* * *} * \\
(0.065)\end{array}$ & $\begin{array}{c}0.121 * * \\
(0.050)\end{array}$ & $\begin{array}{c}0.015 \\
(0.476)\end{array}$ & $\begin{array}{l}-0.045 \\
(0.134)\end{array}$ & $\begin{array}{l}-0.109 \\
(0.123)\end{array}$ & $\begin{array}{l}-0.011 \\
(0.087)\end{array}$ & $\begin{array}{c}0.046 \\
(0.072)\end{array}$ \\
\hline Radio & $\begin{array}{l}-0.007 \\
(0.036)\end{array}$ & $\begin{array}{c}0.030 \\
(0.023)\end{array}$ & $\begin{array}{c}0.070 \\
(0.233)\end{array}$ & $\begin{array}{c}0.028 \\
(0.043)\end{array}$ & $\begin{array}{c}0.007 \\
(0.056)\end{array}$ & $\begin{array}{l}-0.021 \\
(0.047)\end{array}$ & $\begin{array}{l}-0.010 \\
(0.047)\end{array}$ \\
\hline Fridge & $\begin{array}{c}0.057 \\
(0.043)\end{array}$ & $\begin{array}{c}0.179 * * * \\
(0.040)\end{array}$ & $\begin{array}{c}0.216 \\
(0.235)\end{array}$ & $\begin{array}{l}-0.070 \\
(0.089)\end{array}$ & $\begin{array}{c}-0.147 * * \\
(0.075)\end{array}$ & $\begin{array}{c}-0.054 \\
(0.078)\end{array}$ & $\begin{array}{l}-0.050 \\
(0.059)\end{array}$ \\
\hline $\mathrm{TV}$ & $\begin{array}{l}-0.029 \\
(0.065)\end{array}$ & $\begin{array}{c}0.009 \\
(0.056)\end{array}$ & $\begin{array}{l}-0.280 \\
(0.327)\end{array}$ & $\begin{array}{c}0.009 \\
(0.074)\end{array}$ & $\begin{array}{c}0.088 \\
(0.075)\end{array}$ & $\begin{array}{c}0.078 \\
(0.074)\end{array}$ & $\begin{array}{l}-0.034 \\
(0.077)\end{array}$ \\
\hline Wealth 1 & $\begin{array}{l}-0.031 \\
(0.054)\end{array}$ & $\begin{array}{c}0.018 \\
(0.035)\end{array}$ & $\begin{array}{c}0.521 \\
(0.442)\end{array}$ & $\begin{array}{l}-0.093 \\
(0.078)\end{array}$ & $\begin{array}{l}-0.085 \\
(0.085)\end{array}$ & $\begin{array}{l}-0.054 \\
(0.077)\end{array}$ & $\begin{array}{l}-0.039 \\
(0.070)\end{array}$ \\
\hline Wealth 2 & $\begin{array}{l}-0.008 \\
(0.049)\end{array}$ & $\begin{array}{c}-0.001 \\
(0.038)\end{array}$ & $\begin{array}{l}0.677 * \\
(0.363)\end{array}$ & $\begin{array}{l}-0.034 \\
(0.071)\end{array}$ & $\begin{array}{c}0.023 \\
(0.079)\end{array}$ & $\begin{array}{c}0.016 \\
(0.067)\end{array}$ & $\begin{array}{l}-0.054 \\
(0.069)\end{array}$ \\
\hline Wealth 4 & $\begin{array}{l}-0.005 \\
(0.049)\end{array}$ & $\begin{array}{c}-0.049 \\
(0.036)\end{array}$ & $\begin{array}{c}-0.797 * * \\
(0.384)\end{array}$ & $\begin{array}{c}0.037 \\
(0.071)\end{array}$ & $\begin{array}{c}0.048 \\
(0.075)\end{array}$ & $\begin{array}{l}-0.039 \\
(0.067)\end{array}$ & $\begin{array}{l}-0.031 \\
(0.063)\end{array}$ \\
\hline Wealth 5 & $\begin{array}{l}-0.124 \\
(0.076)\end{array}$ & $\begin{array}{c}-0.159 * * * \\
(0.061)\end{array}$ & $\begin{array}{l}-0.337 \\
(0.670)\end{array}$ & $\begin{array}{c}0.147 \\
(0.136) \\
\end{array}$ & $\begin{array}{c}0.183 \\
(0.133) \\
\end{array}$ & $\begin{array}{c}0.017 \\
(0.117) \\
\end{array}$ & $\begin{array}{l}-0.002 \\
(0.109) \\
\end{array}$ \\
\hline District FE & Yes & Yes & Yes & Yes & Yes & Yes & Yes \\
\hline Birth year FE & Yes & Yes & Yes & Yes & Yes & Yes & Yes \\
\hline First stage (F-stat.) & 12.145 & 11.736 & 12.145 & 9.145 & 10.499 & 11.240 & 12.145 \\
\hline Observations & 883 & 723 & 883 & 859 & 863 & 879 & 883 \\
\hline
\end{tabular}

Notes: Standard errors in parentheses are clustered at the birth-year*district level. Statistical levels of significance are: * indicates $\mathrm{p}<0.1$, ** indicates $\mathrm{p}<0.05, * * *$ indicates $\mathrm{p}<0.01$. The sample comprises the FPE cohort (those born during the period 1990 to 1993 ) and those born during the period 1980 to 1985. Instrument: interaction of FPE cohort and $R$, where $R$ is the logarithm of total funding allocated for primary school education for every 100 teachers in each district in 2004. Regressions are weighted by sample weight from the SLDHS. 
Table 8

The Impact of Schooling on Preferences - Instrumental Variables Regressions - Females (Sample of Non-Movers)

\begin{tabular}{|c|c|c|c|c|c|c|c|}
\hline & (1) & (2) & (3) & (4) & (5) & (6) & (7) \\
\hline & \multicolumn{7}{|c|}{ Dependent variables } \\
\hline & $\begin{array}{c}\text { Modern } \\
\text { contracep } \\
\text {-tives }\end{array}$ & $\begin{array}{c}\text { Tested } \\
\text { for AIDS }\end{array}$ & $\begin{array}{l}\text { Desired } \\
\text { number } \\
\text { of } \\
\text { children }\end{array}$ & $\begin{array}{l}\text { Wife } \\
\text { justified in } \\
\text { refusing } \\
\text { sex when } \\
\text { tired }\end{array}$ & $\begin{array}{c}\text { Wife } \\
\text { justified } \\
\text { in } \\
\text { refusing } \\
\text { sex with } \\
\text { STD } \\
\text { husband }\end{array}$ & $\begin{array}{l}\text { Wife } \\
\text { beating } \\
\text { justified } \\
\text { in } \\
\text { refusing } \\
\text { sex }\end{array}$ & $\begin{array}{c}\text { Stop } \\
\text { Female } \\
\text { Genital } \\
\text { Mutilati } \\
\text {-on }\end{array}$ \\
\hline \multirow[t]{2}{*}{ Schooling } & $0.055^{*}$ & $0.043^{*}$ & $-0.227 *$ & 0.005 & 0.054 & $-0.064 * *$ & $0.051 *$ \\
\hline & $(0.032)$ & $(0.023)$ & $(0.126)$ & $(0.028)$ & $(0.037)$ & $(0.030)$ & $(0.029)$ \\
\hline \multirow[t]{2}{*}{ Christian } & 0.004 & 0.035 & $(0.098)$ & 0.031 & $(0.013)$ & 0.048 & $0.100^{* *}$ \\
\hline & $(0.039)$ & $(0.025)$ & $(0.161)$ & $(0.038)$ & $(0.054)$ & $(0.038)$ & $(0.040)$ \\
\hline \multirow[t]{2}{*}{ Temne } & $(0.001)$ & 0.025 & 0.117 & 0.060 & $0.091 * *$ & 0.030 & $(0.026)$ \\
\hline & $(0.033)$ & $(0.027)$ & $(0.135)$ & $(0.045)$ & $(0.042)$ & $(0.039)$ & $(0.039)$ \\
\hline \multirow[t]{2}{*}{ Mende } & $(0.006)$ & 0.009 & 0.031 & $-0.138 * * *$ & $(0.012)$ & $(0.043)$ & $(0.043)$ \\
\hline & $(0.040)$ & $(0.035)$ & $(0.187)$ & $(0.043)$ & $(0.055)$ & $(0.051)$ & $(0.049)$ \\
\hline \multirow[t]{2}{*}{ Urban } & $(0.064)$ & $(0.024)$ & 0.040 & (0.004) & $(0.049)$ & 0.052 & 0.025 \\
\hline & $(0.040)$ & $(0.032)$ & $(0.218)$ & $(0.051)$ & $(0.061)$ & $(0.053)$ & $(0.054)$ \\
\hline \multirow[t]{2}{*}{ Married } & 0.000 & 0.065 & 0.324 & $(0.049)$ & 0.073 & 0.006 & (0.006) \\
\hline & $(0.064)$ & $(0.051)$ & $(0.308)$ & $(0.067)$ & $(0.079)$ & $(0.076)$ & $(0.065)$ \\
\hline \multirow[t]{2}{*}{ Employed } & $0.056^{*}$ & 0.015 & 0.045 & $-0.069^{*}$ & $(0.025)$ & 0.011 & (0.013) \\
\hline & $(0.033)$ & $(0.025)$ & $(0.139)$ & $(0.037)$ & (0.044) & $(0.036)$ & $(0.036)$ \\
\hline \multirow[t]{2}{*}{ Radio } & $-0.038 *$ & $-0.036^{*}$ & 0.086 & 0.032 & $(0.010)$ & $(0.001)$ & $(0.035)$ \\
\hline & $(0.021)$ & $(0.019)$ & $(0.143)$ & $(0.031)$ & $(0.033)$ & $(0.031)$ & (0.033) \\
\hline \multirow[t]{2}{*}{ Fridge } & $(0.070)$ & $(0.036)$ & 0.026 & 0.039 & $-0.107 * *$ & $(0.035)$ & 0.094 \\
\hline & $(0.061)$ & (0.034) & $(0.182)$ & $(0.052)$ & $(0.055)$ & $(0.044)$ & (0.080) \\
\hline \multirow[t]{2}{*}{ TV } & 0.054 & $(0.058)$ & 0.141 & 0.068 & 0.021 & 0.043 & $(0.045)$ \\
\hline & $(0.058)$ & $(0.040)$ & $(0.248)$ & $(0.069)$ & $(0.068)$ & $(0.057)$ & (0.064) \\
\hline \multirow[t]{2}{*}{ Wealth 1} & $(0.022)$ & $(0.031)$ & 0.218 & 0.047 & $(0.020)$ & $-0.108 * *$ & $(0.007)$ \\
\hline & $(0.030)$ & $(0.031)$ & $(0.194)$ & (0.044) & $(0.055)$ & $(0.049)$ & $(0.037)$ \\
\hline \multirow[t]{2}{*}{ Wealth 2} & $(0.017)$ & $(0.001)$ & $0.481 * *$ & 0.005 & 0.009 & $(0.029)$ & 0.004 \\
\hline & $(0.031)$ & $(0.029)$ & $(0.201)$ & $(0.045)$ & (0.053) & $(0.042)$ & (0.031) \\
\hline \multirow[t]{2}{*}{ Wealth 4} & $(0.010)$ & $-0.056^{*}$ & 0.237 & 0.030 & $(0.070)$ & $-0.099 *$ & (0.011) \\
\hline & $(0.042)$ & $(0.033)$ & $(0.235)$ & (0.049) & $(0.056)$ & $(0.055)$ & $(0.052)$ \\
\hline \multirow[t]{2}{*}{ Wealth 5} & $(0.034)$ & $(0.018)$ & 0.007 & $(0.011)$ & (0.107) & $(0.023)$ & $(0.002)$ \\
\hline & $(0.071)$ & $(0.060)$ & $(0.328)$ & $(0.083)$ & $(0.096)$ & $(0.068)$ & $(0.084)$ \\
\hline District FE & Yes & Yes & Yes & Yes & Yes & Yes & Yes \\
\hline Birth year FE & Yes & Yes & Yes & Yes & Yes & Yes & Yes \\
\hline First stage (F-stat.) & 13.628 & 13.026 & 13.628 & 14.283 & 13.186 & 13.364 & 13.628 \\
\hline Observations & 1,612 & 1,589 & 1,612 & 1,585 & 1,600 & 1,608 & 1,612 \\
\hline
\end{tabular}

Notes: Standard errors in parentheses are clustered at the birth-year*district level. Statistical levels of significance are: * indicates $\mathrm{p}<0.1$, ** indicates $\mathrm{p}<0.05, * * *$ indicates $\mathrm{p}<0.01$. The sample comprises the FPE cohort (those born during the period 1990 to 1993 ) and those born during the period 1980 to 1985. Instrument: interaction of FPE cohort and $R$, where $R$ is the logarithm of total funding allocated for primary school education for every 100 teachers in each district in 2004. Regressions are weighted by sample weight from the SLDHS. 


\section{References}

Banerjee, Abhijit, Shawn Cole, Esther Duflo and Leigh Linden. 2007. "Remedying Education: Evidence from Two randomized Experiments in India." The Quarterly Journal of Economics, 122:3, pp. 1235-64.

Becker, Gary S. and Casey B Mulligan. 1997. "The Endogenous Determination of Time Preference." The Quarterly Journal of Economics, 112:3, pp. 729-758.

Chong, Alberto and Eliana La Ferrara. 2009. "Television and Divorce: Evidence from Brazilian NOVELAS," Journal of the European Economic Association, 7:2-3, pp. 458-68.

Chou, Shin-Yi, Jin-Tan Liu, Michael Grossman, and Ted Joyce. 2010. "Parental Education and Child Health: Evidence from a Natural Experiment in Taiwan." American Economic Journal: Applied Economics, 2:1, pp. 33-61.

Currie, J. and E. Moretti. 2003. "Mother's education and the intergenerational transmission of human capital: evidence from college openings." Quarterly Journal of Economics, Vol. 118, pp. 1495-1532.

Cutler, D. and A. Lleras-Muney. 2010. "Understanding Differences in Health Behaviors by Education." Journal of Health Economics, 29, pp.1-28.

Dahl, Gordon B. and Enrico Moretti. 2008. "The Demand for Sons.” Review of Economic Studies, 75: 4, pp. 1085-1120.

Dee, Thomas S. 2004. “Are There Civic Returns To Education?” Journal of Public Economics, volume 88, issue 9-10, pp. 1697-1720.

Duflo, Esther. 2001. "Schooling and Labor Market Consequences of School Construction in Indonesia: Evidence from an Unusual Policy Experiment." American Economic Review, 91:4 pp. 795-813.

Duflo, Esther. 2011. “Women's Empowerment and Economic Development.” NBER Working Paper. No: 17702.

Durkheim, Emile, 1933. The Division of Labor in Society. New York: MacMillan

Galor, Oded and David N. Weil. 1996. "The Gender Gap, Fertility, and Growth.” American Economic Review, 86:3, pp. 374-87.

Grossman, Michael. 1972a. "On the Concept of Health Capital and the Demand for Health." Journal of Political Economy, 80:2, pp. 223-255. 
Grossman, Michael. 1972b. The Demand for Health: A Theoretical and Empirical Investigation. New York: Columbia University Press for the National Bureau of Economic Research.

Grossman, M. 2008. "The Relationship between Health and Schooling." Eastern Economic Journal, 34:3, pp. 281-92.

Hanushek, Eric A. and Dennis Kimko. 2000. "Schooling, Labor Force Quality, and the Growth of Nations." American Economic Review, 90:5, pp. 1184-1208.

International Monetary Fund. 2001. Republic of Sierra Leone Interim Poverty Reduction Strategy Paper. Freetown: Sierra Leone. http://www.imf.org/external/np/prsp/2001/sle/01/063101.pdf (Accessed July 19, 2010).

Jensen, Robert and Emily Oster. 2009. "The Power of TV: Cable Television and Women's Status in India." The Quarterly Journal of Economics, 124:3, pp. 1057-1094.

Knowles, Stephen, Paula K. Lorgelly, and P. Dorian Owen. 2002. "Are Educational Gender Gaps a Brake on Economic Development? Some Cross-Country Empirical Evidence." Oxford Economic Papers, 54:1, pp. 118-149.

Lagerlöf, Nils-Petter. 2003. "Gender Equality and Long-Run Growth.” Journal of Economic Growth, 8:4, pp. 403-26.

Lleras-Muney, Adriana. 2005. "The Relationship between Education and Adult Mortality in the United States." Review of Economic Studies, 72:1, pp. 189-221.

Mocan, Naci and Duha Altindag, 2012. "Education, Cognition, Health Knowledge and Health Behavior." NBER working paper No: 17949

Osili, Una Okonkwo and Bridget Terry Long. 2008. "Does female schooling reduce fertility? Evidence from Nigeria." Journal of Development Economics, Volume 87, pp. 57-75.

Psacharopoulos, George. 1994. "Returns to investment in education: A global update." World Development, 22:9, pp. 1325-1343.

Schultz, T. Paul. 2002. "Why Governments Should Invest More to Educate Girls." World Development, 30:2, pp. 207-225.

Statistics Sierra Leone and ICF Macro. 2009. Sierra Leone Demographic and Health Survey 2008: Key Findings. Calverton, Maryland, USA: SSL and ICF Macro. http://www.measuredhs.com/pubs/pdf/SR171/SR171.pdf (Accessed April 17, 2012) 
UNDP. 2007. Sierra Leone Human Development Report. Freetown: UNDP. http://hdr.undp.org/en/reports/nationalreports/africa/sierraleone/sierraleone_nhdr_20 071.pdf (Accessed July 22, 2010)

UNESCO Institute for Statistics. 2011. Global Education Digest 2011: Comparing Education Statistics Across the World. UNESCO, Montreal: UIS. http://www.uis.unesco.org/Library/Documents/global_education_digest_2011_en.pd f (Accessed April 17, 2012)

Weber, Max. 1964 [1922]. The Sociology of Religion. Boston: Beacon.

World Bank. 2007. Education in Sierra Leone: Present Challenges, Future Opportunities United Nations. African Human Development Series. World Bank: Washington, D.C.

http://www.sierraleoneportal.net/rainbow/Portals/_EduSL/Documents/CSR_eBook\% 20(Sierra\%20Leone).pdf (Accessed July 15, 2010).

World Health Organization. 2008. Eliminating Female Genital Mutilation: An Interagency Statement. Department of Reproductive and Health Research. World Health Organization: Geneva, Switzerland.

http://www.un.org/womenwatch/daw/csw/csw52/statements_missions/Interagency_S tatement_on_Eliminating_FGM.pdf (Accessed April 17, 2012)

World Health Organization. 2010. Manual for early infant male circumcision under local anaesthesia. World Health Organization: Geneva, Switzerland. http://whqlibdoc.who.int/publications/2010/9789241500753_eng.pdf (Accessed April 17, 2012) 


\section{Appendix 1}

\section{Preference questions as appearing in the SLDHS}

1. If you could go back to the time you did not have children and could choose exactly the number of children to have in your whole life, how many would that be? Or for those with no living children, the following question was asked: If you could choose exactly the number of children to have in your whole life, how many would that be?

2. Is a wife justified in refusing to have sex with her husband when she is tired or not in the $\operatorname{mood}$ ?

3. Have you ever used any (any of the contraceptive methods)?

4. I don't want to know the results, but have you ever been tested to see if you have AIDS?

5. Husband and wives do not always agree in everything. If a wife knows her husband has a disease that she can get during sexual intercourse, is she justified in refusing to have sex with him?

6. Sometimes a husband is annoyed or angered by the things that his wife does. In your opinion, is a husband justified in hitting or beating his wife in the following situations: if she refuses to have sex with him? (Other situations were given to the respondent as well)

7. Do you think that this practice (female genital cutting) should be continued, or should it be stopped? 